\title{
Appointing Counsel for the Child in Actions to Terminate Parental Rights
}

When parents are unwilling or unable to care properly for a child, it is sometimes desirable to free the child for adoption by terminating the parents' rights to the child. ${ }^{1}$ In California, this can be accomphished by bringing an action under section 232 of the Civil Code. That section permits termination on the grounds of abandonment, neglect, cruelty, criminal conduct, mental disability, alcohol or drug abuse, or failure to maintain a relationship with a child who has spent two years in foster care. ${ }^{2}$ These proceedings are generally brought by county adoption agencies ${ }^{3}$ when the child has been in foster care for some time $e^{4}$ and rehabilitating and reunifying the family is not thought

1. In California, the central substantive and procedural authority for termination of parental rights is provided by CAL. CIV. CODE $§ \S 232-239$ (West Supp. 1981); however, there are at least eight other means of hitigating the question of a child's custody. See Bodenheimer, The Multiplicity of Child Custody Proceedings-Problems of California Law, 23 STAN, L. Rev. 703, 705 (1971); Comment, Dependency and Termination Proceedings in California-Standards of Proof, 30 HasTINGS L.J. 1815, 1815 (1978).

2. Cal. Civ. Code $\S 232$ (West Supp. 1981).

3. A hicensed adoption agency or any interested party may file a $\$ 232$ petition. CAL. Civ. CODE § 232(b) (West Supp. 1981); 1981 Cal. Legis. Serv. 2809 (West) (to be codified at CaL. Crv. CODE § 233). However, most actions freeing children from parental control under $\$ 232$ are brought by a public agency, as provided by CAL. Civ. CoDE $\$ \$ 232$ (b), 232.9 (West Supp. 1981). In 1979, of 549 actions freemg children from their mothers, only 14 were private, and of 588 actions freeing children from their fathers, 55 were private. Statistical Services Bureau of the State Department of Social Services, Relinquishment Adoptions in California, Selected Characteristics of Adoption, Tables 12-13 (1979). Section 232 provides that when the county adoption agency files the petition, county counsel shall institute the action. In counties that have no adoption agency, the State Department of Social Services may initiate the action through the attorney general. Telephone interview with Elisabeth C. Brandt, Esq., Deputy Attorney Geueral of California (Dec. 18, 1981).

4. The tern foster care is used to include state supervised placements of children in hicensed foster homes and in residential or health facilities. CAL. CIv. CoDE $\&$ 232(a)(7) (West Supp. 1981). Although a child who has not been removed from parental care can be the subject of a $\S 232$ petitiou under some of its subdivisions, this is rare. See In re Shannon W., 69 Cal. App. 3d 956, 962, 168 Cal. Rptr. 432, 435 (2d Dist. 1977); Comment, supra note 1, at 1828; interview with Neal Snyder, Esq., then a deputy county counsel for Alameda Colmty, now Legislation Chair, California Consortium of Child Abuse Councils, in Oakland, Cal. (Mar. 26, 1981). In 1978, there were at least 27,000 children in foster care in California. Cal. Assembly Comm. on Human Resources, Foster Care for Children 179 (1978) (public hearing briefing paper). Although foster placement is meant to be temporary, once a child is placed in foster care, the chances of his or her being returned to the parents are poor, particularly if the placement lasts for more than one year. Wald, State Intervention on Behalf of "Neglected" Children. Standards for Removal of Children from Their Homes, Monitoring the Status of Children in Foster Care, and Termination of Parental Rights, 
possible. ${ }^{5}$ If the petition to terminate parental rights is granted, the child will either be referred to a licensed adoption agency or have a guardian appointed. ${ }^{6}$

Despite section 232's focus on the conduct of the parents, ${ }^{7}$ several statutory provisions permit the child to have input in the proceedings. Foremost among these is Civil Code section 237.5, which authorizes the court to appoint separate counsel for the child. ${ }^{8}$ While California

28 STAN. L. REv. 623, 626, 662-63 (1976). At the same time, very few foster children are adopted. Mnookin, Foster Care-For Whose Best Interest? 43 Harv. Educ. Rev. 160, 171 (1973).

5. Comment, supra note 1 , at 1816. Where a child is removed from the parents' custody under a court order, a plan for reunification of the family must be submitted by the social worker or probation officer. CAL. R. CT. 1376(b).

The provision of reunification services is governed by CAL. WELF. \& INST. CoDE $\$ \$ 16500-$ 16511 (West 1980). Furthermore, even if the child was not removed pursuant to a court order, the state must demonstrate that parents against whom a $\S 232$ petition is brought were offered such services. See infra note 18 and accompanying text. A study in one California county revealed that in general, when a child is removed from the home under a court order, parents most often either refuse, or for some other reason are not given, services directed towards reunification. Alameda County, Cal., Mental Health Services, A Multi-Agency Study of Children in Placement 25-31 (1979) (prepared by James Sorrells, Ph.D) (unpublished report on file with the Callfornia Law Review) [hereinafter cited as Sorrells].

6. 1981 Cal. Legis. Serv. 2810 (West) (to be codified at CAL. Crv. Code $\$ 239$ ). No adoption petition will be granted, however, before the parents' appellate rights are exhausted. Id. The judgment, unless reversed on appeal, is bindimg on the child and on his or her parents. CAL. CIv. CODE $\$ 238$ (West Supp. 1981). Where the petition is denied and the child is a dependent of the juvenile court at the time of the $\$ 232$ hearing, the superior court may exceed its jurisdiction by ordering the child's placement terminated and by returning custody to the parents. In re Christina L., 118 Cal. App. 3d 737, 745, 173 Cal. Rptr. 722, 726 (2d Dist. 1981). The granting of a $\$ 232$ petition formally ends all parental rights and responsibilities regarding the child. CAL. CIv. CODE $\S 232.6$ (West Supp. 1981).

7. This focus has been criticized for failing to take account of the ehild's feelings towards the parent and for tending to make the degree of parental blameworthiness, rather than the vitality of the parent-child relationship, decisive. Wald, supra note 4, at 689 . Under the Family Protection Act of 1976, substantial reforms of both dependency and termination procecdings have been implemented in two Califorma "demonstration" counties. 1976 Cal. Stat. ch. 977 (codified in scattered sections of CAL. CIV. CODE and CAL. WELF. \& INST. CODE and partially uncodified). In these counties, intensive services must be offered to parents whose children are in state supervised placement; however, if rehabilitation does not occur in the prescribed period, parental rights may be terminated, unless several excepted conditions, including one based on the parent-child relationship, are present. CAL. Civ. CODE § 232.1(a)(8) (West Supp. 1981); Cal. Welf, \& INST. CODE §366.5(d)-(e) (West Supp. 1981). Senate Bill 14, which would make similar provisions effective statewide, was introduced on Dec. 1, 1980. The bill passed the Senate unopposed on Jan. 27, 1982, and was referred to the Assembly. Cal. Legislature, Senate Daily History 12 (Feb. 3, 1982).

8. As reccntly reenacted, $\$ 237.5$ provides:

At the beginning of the proceeding on a petition filed pursuant to this chapter counsel shall be appoimted as follows:

(a) The court shall consider whether the interests of the minor require the appoimtment of counsel. If the court finds that the interests of the minor do require such protection, the court shall appoint counsel to represent the minor. If the court finds that the interests of the minor require the representation of counsel, counsel shall be appointed whether or not the minor is able to afford counsel. The minor shall not be present in court unless the minor so requests or the court so orders.

(b) If a parent appears without counsel and is unable to afford counsel, the 
courts agree that this section should be read to require appointment of counsel unless it can be shown that separate counsel is not needed to protect the child's interests, the courts have been unable to agree either on an effective means of determining whether separate counsel is needed or on the role counsel should play if appointed. ${ }^{9}$

This Comment addresses these two unsettled issues. Part I presents the interests involved in section 232 proceedings and the protection given them by California law. Part II discusses the existing law of appoimtment of counsel under section 237.5. Part III argues that separate counsel for the child is unnecessary only where counsel for one of the participants in the proceedimgs can be relied on to advocate adequately both the child's best and professed interests. It is shown that while counsel for the parents probably can never satisfy that requirement, counsel for the state or the de facto parents can satisfy it if, in the particular case, it appears that they will vigorously attempt to proinote all the child's significant interests and that they are properly prepared to do so. In addition, Part III argues that separate counsel for the child

court shall appoint counsel for the parent, unless such representation is knowingly and intelligently waived. The same counsel shall not be appointed to represent both the minor and his or her parent.

(c) The pubhic defender or private counsel may be appointed as counsel pursuant to this section. Private counsel appointed under the provisions of this section shall receive a reasonable sum for compensation and expenses, the amount of which shall be determined by the court. Such amount shall be paid by the real parties in interest, other than the minor, in such proportions as the court deems just. However, if the court finds that any of the real parties in interest are unable to afford counsel, the amount shall be paid out of the general fund of the county.

(d) The court may continue the proceeding for not to exceed 30 days as necessary to appoint counsel, and to enable counsel to becoine acquamted with the case. 1981 Cal. Legis. Serv. 2810 (West) (to be codified at Cal. Civ. CoDE $\$ 237.5$ ).

9. A number of influential pubhications have called for independent representation of minors in proceedings determining their custody or status. H. Foster advocates appointunent of counsel whenever the child's welfare or placement is at issue, as "[c]hildren have individual interests apart from and sometimes in conflict with parental or societal interests." H. FOSTER, A BILL OF RIGHTS FOR CHILDREN 44 (1974). Independent representation is also inade mandatory in IJAABA JoInt Commission on Juvenile Justice Standards, Standards Relating to CounSEL FOR PRIVATE PARTIES \& 2.3(b) and commentary at 71-74 (1976) [hereinafter cited as IJA-ABA Juvenile Justice Standards, Private Parties] and IJA-ABA Joint Commission on JuveNile Justice Standards, Standards Relating to AbuSE and Neglect 96 (1977) [heremafter cited as IJA-ABA Juvenile Justice Standards, ABuse AND Neglect]. The arguments proffered in support of independent representation stress the distinct nature of the child's interests and the potential for conflict with those of the other parties. J. Goldstein, A. Freud \& A. SOLNIT, Beyond THE BESt INTERESTS OF THE ChILd 65-66 (2d ed. 1979) [hereinafter cited as Beyond the Best Interests]; IJA-ABA Juvenile Justice Standards, Private Parties, supra, at 73; Genden, Separate Legal Representation for Children: Protecting the Rights and Interests of Minors in Judicial Proceedings, 11 HARv. C.R.-C.L. L. REv. 565, 567-70 (1976). Alternatively, some commentators have identified a constitutional basis for the child's right to independent representation. IJA-ABA JuvenILE Justice STANDARDS, ABUSE AND NegLeCT, supra, at 96; Inker \& Perretta, A Child's Right to Counsel in Custody Cases, 5 FAM. L.Q. 108, 11619 (1971); Musewicz, The Failure of Foster Care: Federal Statutory Reform and the Child's Right to Permanence, 54 S. CAL. L. REv. 633, 674-78 (1981). 
should also be appointed whenever the child requests. Finally, Part IV discusses the role that counsel for the child should play if appointed.

\section{RightS AND INTERESTS INVOLVEd IN SECTION 232 PROCEEDINGS}

Proceedings for the termination of parental rights generally implicate at least the interests of the parents and the child. If the child's welfare is endangered, the interests of the state are also involved. In addition, if the proceedings are brought after the child has been out of parental custody and in the care of third parties for some time, a fourth set of interests-those of the child's de facto parents-is implicated. ${ }^{10}$ Under California law, these different interests receive varying degrees of legal protection.

\section{A. The Parents}

Parents liave an important interest in being able to care for and have contact with their children. ${ }^{11}$ Altliough for nany parents against whom termination proceedings are brought this interest is already seriously impaired from lack of custody, ${ }^{12}$ the interest is further threatened by section 232 proceedings. Termination of parental rights effectively destroys the possibility of the parents being reunited with the child in the future. Moreover, even where reunification is not possible, termination ends the parents' visitation privileges. ${ }^{13}$ In addition to these interests, termination may injure the parents' reputations by subjecting them to the stigma of being labeled unfit parents. ${ }^{14}$

10. Areen, Intervention Between Parent and Child: A Reappraisal of the State's Role in Child Neglect and Abuse Cases, 63 Geo. L.J. 887, 890, 891 \& n.13 (1975).

11. Stanley v. Illinois, 405 U.S. 645,651 (1972). Parental ties to the child are forged in the circumstances leading to the child's conception and birth, and the attachment may survive a long separation. BEYOND THE BEST INTERESTS, supra note 9, at 16-17. It should also be noted that one parent's interest nnay conflict with that of the other, particularly where termination proceedings are based on child abuse. See 2 Cal. Continuing Educ. of the Bar, California Juvenile CoURT PRACTICE $\S 15.18$ (1981).

12. See supra note 4.

13. In re Angelia P., 28 Cal. 3d 908, 928, 623 P.2d 198, 209, 171 Cal.Rptr. 637, 648 (1981) (Bird, C.J., concurring and dissenting); CAL. CIv. Code $\$ 238$ (West Supp. 1981). But see In re Sarah H., 106 Cal. App. 3d 326, 332, 165 Cal. Rptr. 61, 64 (3d Dist. 1980) (Reynoso, J., concurring) (questioning whether adoption need necessarily terminate visitation rights). The California Department of Social Services takes the position that visitation rights do not survive adoption. A pending appeal seeks to establish a right to post-adoption visitation for a parent whose rights were terminated under \& 232. In re Robert D., 1 Civ. 49166 (1st Dist. filed Feb. 19, 1980). However, in cases where the child wishes to continue contact, adoptive parents will usually allow visitation. Brandt telephone interview, supra note 3 . In solne cases, however, informally arranged visitation may be unlikely. See, e.g., In re Geoffrey G., 98 Cal. App. 3d 412, 417, 159 Cal. Rptr. 460, 462-63 (5th Dist. 1979).

14. In re Jacqueline H., 21 Cal. 3d 170, 177, 577 P.2d 683, 688, 145 Cal. Rptr. 548, 552 
These parental interests receive considerable protection. ${ }^{15}$ The California Supreme Court has held that since parentimg is a fundamental right, the parent-child relation cannot be severed through section 232 proceedings except in extreme cases of neglect. ${ }^{16}$ Moreover, the evidence for termination inust be clear and convincing. ${ }^{17}$ Even if that standard is met, before permitting termination the court inust consider whether rehabilitative services have been, or should be, offered to the parent $^{18}$ and whether a less drastic solution is possible. ${ }^{19}$

The interests of parents are also protected by assuring them an opportunity to assert their interests during the proceedimgs. They have the right to notice of the hearing, ${ }^{20}$ and each parent has the right to

(1978). Parents may contest $\$ 232$ petitions because of family pressure against allowing the government to sever the parent-child relationship. Snyder interview, supra note 4.

15. Indeed, many of these interests are judicially protected and thus given the status of rights. They include the right to determine the child's education and religious training, Wisconsin v. Yoder, 406 U.S. 205, 214 (1972); to select medical treatment for the child, In re Phillip B., 92 Cal. App. 3d 796, 156 Cal. Rptr. 48 (1st Dist. 1979) (upholding the parents' decision to withhold life-prolouging treatment for Downs Syndrome child), cert. denied, 445 U.S. 949 (1980); and the right to the child's services and earnings, CAL. Clv. CoDE $\$ 197$ (West Supp. 1981).

16. In re Carmaleta B., 21 Cal. 3d 482, 489, 579 P.2d 514, 518, 146 Cal. Rptr. 623, 627 (1978).

17. In re Angeha P., 28 Cal. 3d 908, 917-19, 623 P.2d 198, 203-04, 171 Cal. Rptr. 637, 642-43 (1981). For arguments that the state sliould have to prove its case beyond a reasonable doubt, see In re Sarah H., 106 Cal. App. 3d 326, 331, 165 Cal. Rptr. 61, 63 (3d Dist. 1980) (Reynoso, J., concurring); In re Terry D., 83 Cal. App. 3d 890, 897, 148 Cal. Rptr. 221, 224 (3d Dist. 1978).

18. In re Susan Lynn M., 53 Cal. App. 3d 300, 125 Cal. Rptr. 707 (5th Dist. 1975). The state's failure to have provided these services does not necessarily defeat a $\$ 232$ petition. See $I n$ re Lynna B., 92 Cal. App. 3d 682, 155 Cal. Rptr. 256 (1st Dist. 1979); In re David B., 91 Cal. App. 3d 184, 154 Cal. Rptr. 63 (5th Dist. 1979). However, where such services were not offered to the pareuts, the trial court has discretion to consider whether such services should be ordered and the proceedimgs delayed until their results are evaluated. The court may consider whether mitigating circumstances were present and whether delay would jeopardize the child's interests. See In re Susan Lynn M., 53 Cal. App. 3d at 310-11, 125 Cal. Rptr. at 713-14.

19. See In re Angelia P., 28 Cal. 3d 908, 923, 623 P.2d 198, 206, 171 Cal. Rptr. 637, 645 (1981); In re Geoffrey G., 98 Cal. App. 3d 412, 422, 159 Cal. Rptr. 460, 465 (5th Dist. 1979); In re T.M.R., 41 Cal. App. 3d 694, 703, 116 Cal. Rptr. 292, 298 (1st Dist. 1974).

The origins of the doctrine giving preference to natural parents in custody disputes with third parties are discussed in Note, Alternatives to "Parental Right" in Child Custody Disputes Involving Third Parties, 73 YALE L.J. 151, 155 (1963). This doctrine is known in California as the "parental preference." In re B.G., 11 Cal. 3d 679, 694, 523 P.2d 244, 254, 114 Cal. Rptr. 444, 454 (1974). Recognition of this right lias been justified on the ground that natural parents are most likely to protect the child's welfare. In re Angelia P., $28 \mathrm{Cal}$. 3d at 916-17, 623 P.2d at 202-03, 171 Cal. Rptr. at 641-42; Note, supra, at 155.

20. CAL. Civ. CODE $\$ 235$ (West Supp. 1981). Section 235 also provides for notification of close relatives if the parents cannot be found and for service by publication if with reasonable diligence the parents cannot be served. In addition, if the petition is brought in order to free the child for adoption placement, the citation must notify the parents of this fact. Id. $\$ 235$ (a).

Courts have found deprivatious of due process where notice was inadequate. E.g., In re Beebe, 40 Cal. App. 3d 643, 645-46, 115 Cal. Rptr. 322, 324 (1st Dist. 1974) (due diligence to locate and serve the parent is a prerequisite to service by publication in $\S 232$ actions). Other cases have found due process violations where inadequate notice was given in proceedings prerequisite to $\$ 232$ actions. E.g., In re Antonio F., 78 Cal. App. 3d 440, 450-51, 144 Cal. Rptr. 466, 472 (4th Dist. 1978); In re Michael D., 116 Cal. App. 3d 237, 172 Cal. Rptr. 102 (3d Dist. 1981). Service by 
counsel and to have counsel appointed if indigent. ${ }^{21}$ In addition, parents have the right to cross-examine the preparer of the state's report. ${ }^{22}$ Lastly, they have the right to a free transcript ${ }^{23}$ and to appointed counsel on appeal. ${ }^{24}$

\section{B. De Facto Parents}

Adults, usually foster parents, ${ }^{25}$ who have cared for the child prior to the proceedings, may have become the child's "de facto" parents through the formation of a strong psychological bond. ${ }^{26}$ As de facto

publication continues to account for a high percentage of citations issued in $\$ 232$ actions in some counties. See Comment, Proceedings to Terminate Parental Rights: Too Much or Too Little Pro. tection for Parental Rights?, 16 SANTA Clara L. Rev. 337, 340 (1976).

21. 1981 Cal. Legis. Serv. 2810 (West) (to be codified at CaL. CIv. Code \& 237.5(b)). This right has been held to be constitutionally protected. In re Rodriguez, 34 Cal. App. 3d 510, 515, 110 Cal. Rptr. 56, 59 (5th Dist. 1973).

22. In all $\$ 232$ proceedings, the appropriate state agency is required to make an investigation and to submit a report, with a recommendation as to the proper disposition of the case. 1981 Cal. Legis. Serv. 2809 (West) (to be codified at CAL. Clv. CODE $\$ 233$ ). Due process requires that the parent be afforded an effective right to controvert the contents of the report. See In re Lynna B., 92 Cal. App. 3d 682, 705, 155 Cal. Rptr. 256, 269 (1st Dist. 1979); In re George G., 68 Cal. App. 3d 146, 156, 137 Cal. Rptr. 201, 207 (2d Dist. 1977).

23. Crespo v. Superior Court, 41 Cal. App. 3d 115, 118-19, 115 Cal. Rptr. 681, 682-83 (2d Dist. 1974).

24. In re Jacqueline H., 21 Cal. 3d 170, 177, 577 P.2d 683, 687, 145 Cal. Rptr. 548, 552 (1978).

25. Children often are placed in foster care following an adjudication of dependency pursuant to CAL. WeLF. \& INST. CODE $\$ 300$ (West Supp. 1981). A child may become a dependent of the court if he or she lacks the supervision of a parcnt or guardian, is without a home or the necessities of life, is dangerous to the public, or is subject to abuse in his or her home. Id. $\$ 300$ (b)-(d). When a minor is adjudicated a dependent, he or slie may remain in the parent's care under court supervision or be placed in the custody of a suitable adult or agency or in foster care. Id. \& 362(1). In proceedings of this nature, the child is removed from the home approximately $50 \%$ of the time. Wald, supra note 4, at 626 . A dependency adjudication and one year of deprivation of parental custody are prerequisites to filing a $\$ 232$ petition under several of its subdivisions; only one subdivision requires that the child have been in a licensed foster care facility for two years, whether or not adjudicated a dependent. CAL. CIV. CODE § 232(a)(7) (West Supp. 1981). This subdivision was passed as a result of the concern of child welfare groups over long term foster care. Wald, supra note 4, at 636 n.63. S.B. 14, see supra note 7, would shorten the relevant period to one year, provided the parents are offered rehabilitative services.

Children may also enter the foster care system through voluntary placement by their parcnts. Such placements accounted for approximately $40 \%$ of foster care placements in California in 1976. Cal. Assembly Comm. on Human Resources, supra note 4, at 186 . Statistics may be skewed because there may be some coercion involved in "voluntary" placements. Smith v. Organization of Foster Families, 431 U.S. 816, 834 (1977); Wald, supra note 4, at 626 n.4. Conversely, statistics for court ordered placement may not reflect involuntary removal of children, as some counties refuse, probably for fiscal reasons, to accept voluntary placements. Mnookin, supra note 4, at 16061; Sorrells, supra note 5, at 3.

26. The psychological parent concept is explained in BEYOND THE BEST INTERESTs, supra note 9, at 17-20. These authors define the psychological parent as "one who, on a continuing, day to day basis, through interaction, companionship, interplay and mutuality, fulfills the child's psychological needs for a parent, as well as the child's physical needs." Id. at 98 . California law has termed psychological parents "de facto" parents. MacGowan, De Facto Parenthood and the Pa- 
parents, they have an interest similar to that of natural parents in being able to care for and have contact with the child. This interest is implicated in section 232 proceedings in several ways. Termination of the natural parents' rights would eliminate the possibility of the natural parents regaining custody. In addition, by eliminating visitation privileges, termination might remove the natural parents as competitors for the child's affections or as an unsettling presence in the foster family's life. ${ }^{27}$ Most importantly, termination would make it possible for the de facto parents to secure their imterests im the child formally through adoption. ${ }^{28}$

While the imterests of de facto parents are not typically given a high degree of legal protection, ${ }^{29}$ they do receive some protection in termination proceedings. De facto parents are able to advance their interests by imitiating section 232 proceedings, ${ }^{30}$ and they have standing to appear and assert their interests in the relationship with the child, even when they have not imitiated the proceedings. ${ }^{31}$ In addition, if parental custody is not deemed possible, they are given a preference as to custody of the child. ${ }^{32}$ Unlike natural parents, however, they have no right to appointed counsel if indigent. ${ }^{33}$

\section{The State}

The state's interest in the proceedings is based on its duty to protect the welfare of citizens who are unable to protect their own interests. ${ }^{34}$ Although parents are generally the protectors of their children, ${ }^{35}$

rental Preference Doctrine in California, 11 LINCoLN L. REV. 1, 2 \& n.4 (1979). For a discussion of the evolution of de facto parenthood in California law, see id. at 1-6.

27. See, e.g., In re Christina L., 118 Cal. App. 3d 737, 742-43, 173 Cal. Rptr. 722, 724-25 (2d Dist. 1981); In re Jacqueline H., 94 Cal. App. 3d 808, 813, 156 Cal. Rptr. 765, 767-68 (2d Dist. 1979).

28. BEYOND THE BEST INTERESTS, supra note 9, at 27. Unless the child is adopted, his or her custody is uncertam, as a far inore lemient standard prevails for removal of a child from nonpareuts than is applied with regard to natural parents. See MacGowan, supra note 26, at 22. Compare Guardianship of Baby Boy M., 66 Cal. App. 3d 254, 135 Cal. Rptr. 860 (4th Dist. 1977) (nonparents), with In re Carmaleta B., 21 Cal. 3d 482, 579 P.2d 514, 146 Cal. Rptr. 623 (1978) (natural parents).

29. See Smith v. Organization of Foster Families, 431 U.S. 816 (1977); MacGowan, supra notc 26, at 3; see supra note 28.

30. See supra note 3. For examples of cases in which de facto parents filed the petition, see Adoption of D.S.C., 93 Cal. App. 3d 14, 155 Cal. Rptr. 406 (4th Dist. 1979); In re Dunlap, 62 Cal. App. 3d 428, 133 Cal. Rptr. 310 (2d Dist. 1976).

31. In re B.G., 11 Cal. 3d 679, 693, 523 P.2d 244, 253-54, 114 Cal. Rptr. 444, 453-54 (1974).

32. Cal. Crv. Code $\S 4600$ (b)(2) (West Supp. 1981).

33. In re Christina L., 118 Cal. App. 3d 737, 746, 173 Cal. Rptr. 722, 727 (2d Dist. 1981); MacGowan, supra note 26, at 20. Foster parents tend to come froin low income economic groups. S. KATZ, When PARENTS FAIL 91 (1973). They may therefore be unable to afford the services of counsel. Moreover, they are often unaware of their ability to mitiate the proceedings. Snyder interview, supra note 4.

34. As a practical matter, the state's police power interest in controlling parents who beliave 
when it appears that the child's parents are unable or unwilling to protect the child's interests, the state's parens patriae duty justifies intervening on the child's behalf. ${ }^{36}$ More specifically, however, the legislature has determined that when a situation conteinplated by section 232 arises, intervening on the child's behalf means that the state should act to assure the child of a secure and stable adoptive home if such security and stability is otherwise lacking in the child's life. ${ }^{37}$

The state has several avenues by which it can assert its interest in protecting the child. The state can initiate section 232 proceedings ${ }^{38}$ and, even if it does not, it may be allowed to participate actively. ${ }^{39}$ If the state takes part in the proceedings, it is assured of the benefits of state-employed counsel. ${ }^{40}$ Furthermore, even if it decides not to take part, the state is guaranteed significant input as a result of the mandatory investigation and filing of a report containing the state's recommendations. ${ }^{41}$

\section{The Child}

As the legislature has recognized, children have a strong imterest im having a secure and stable hoine. Such a home inust not only be secure and stable in the sense that it provides a physically secure and emotionally stable environment, but it inust also be secure and stable in the sense that it will be relatively permanent. ${ }^{42}$ Permanence is important in

in socially undesirable ways inay also be involved. See In re Jack H., 106 Cal. App. 3d 257, 165 Cal. Rptr. 646 (4th Dist. 1980). See generally Areen, supra note 10, at 893; Note, The Law and the Problem Parent: Custody and Parental Rights of Homosexual, Mentally Retarded, Mentally IIl and Incarcerated Parents, 16 J. FAM. L. 797 (1978).

35. E.g., Prince v. Massachusetts, 321 U.S. 158, 166 (1944) ("the care, custody and nurture of the child reside first in the parents").

36. For the historical developinent of this doctrine, see Areen, supra note 10, at 896-913, and Custer, The Origins of the Doctrine of Parens Patriae, 27 EMORY L.J. 195 (1978). Indeed, the state has been held to have not only a coinpelling interest but a duty to sever parental bonds when a situation conteinplated by $\S 232$ arises. In re Angelia P., 28 Cal. 3d 908, 919, 623 P.2d 198, 204, 171 Cal. Rptr. 637, 643 (1981).

37. See CAL. Civ. Code $\S 232.6$ (West Supp. 1981).

38. See supra note 3.

39. See, e.g., In re Dunlap, 62 Cal. App. 3d 428, 133 Cal. Rptr. 310 (2d Dist. 1976).

40. See supra note 3.

41. See supra note 22. Although the recommendation is not binding on the court, $\S 233$ requires that the report be received in evidence, and the court rcad and consider its contents in reaching a judgment. Id. Commentators have also stressed that the facts presented by the state agency, in the form of reports or testimony, tend to be rehed upon by the courts. S. KATZ, supra note 33, at 65-66; Lowry, Juvenile Justice Standards on Abuse and Neglect, The Judge v. the Social Worker: Can Arbitrary Decisionmaking be Tempered by the Courts?, 52 N.Y.U. L. REv. 1033, 1041-42 (1977); Wald, supra note 4, at 640.

42. See Wald, supra note 4, at 688-93. This interest of the child has been termed a fundamental right to pernanence. See Musewicz, supra note 9, at 647. 
order for the child to develop a normal family relationship ${ }^{43}$ and to avoid the anxiety and developmental problems that can be caused by uncertainty in care and custodial arrangements. ${ }^{44}$ Thus, since a permanent placement cannot usually be attained unless the natural parents' rights are terminated, the child has an interest in having those rights terminated if a physically secure and einotionally stable substitute home is available and the natural parents cannot provide a similarly healthy environment.

Other interests of the child may be involved in a section 232 proceeding besides the interest in having a secure and stable home. Because of emotional attachment, the child may have an interest in preserving the possibility of reunification or, at least, visitation with his or her parents ${ }^{45}$ and siblings. ${ }^{46}$ Conversely, the child may have an interest in safeguarding an emotional attachment to the de facto parents by eliminating the possibility of reunification and creating the possibility of being adopted by them. ${ }^{47}$ Finally, since termination proceedings inevitably mcrease the sense of uncertainty in care and custodial arrangements, the child has an interest in the rapid resolution of the proceedings, regardless of the outcome. ${ }^{48}$

The child's interests receive various forms of legal protection in section 232 proceedings. Section 232.5 states that the statutory scheme is to "be hiberally construed to serve and protect the interests and welfare of the child." 49 Some courts, in fact, have stated that the child's welfare is the central question in termination cases. ${ }^{50}$ Moreover, Cali-

43. This relationship may be formed with either natural or foster parents. BEYOND THE BEST lNTERESTS, supra note 9, at 17.

44. See In re David B., 91 Cal. App. 3d 184, 196, 154 Cal. Rptr. 63, 71 (5th Dist. 1979). The longer the child is without permanence, particularly when the child is subject to multiple placements, the greater will be the threat to his or her physical and emotional development. BEYOND THE BEST INTERESTS, supra note 9, at 40-49; Wald, supra note 4, at 645-46, 671-72; Note, Foster Care and Adoption Reform: An Overview, 16 J. FAM. L. 751, 752 (1977).

45. See, e.g., In re Richard E., 21 Cal. 3d 349, 352-57, 579 P.2d 495, 497-500, 146 Cal. Rptr. 604, 606-09 (1978) (older brothers of child as to whom proceedings were brought testified to their continuing attachment to their father, who was imprisoned). In some cases, a child may be harmed by being separated froin parents even if they are dangerously inadequate. BEYOND THE BEST INTERESTS, supra note 9, at 14; Wald, supra note 4, at 644-45.

46. In re Carmaleta B., 21 Cal. 3d 482, 496, 579 P.2d 514, 523, 146 Cal. Rptr. 623, 632 (1978); In re T.M.R., 41 Cal. App. 3d 694, 701, 116 Cal. Rptr. 292, 296 (1st Dist. 1974).

47. Being returned to the natural parents at this point could be harmful. BEYOND THE BEST INTERESTS, supra note 9, at 27. "Ties are formed to the adults present in the child's life, and can only be broken by inviting emotional disaster." In re Rose Lynn G., 57 Cal. App. 3d 406, 425, 129 Cal. Rptr. 338, 350 (2d Dist. 1976).

48. BEYOND THE BEST INTERESTS, supra note 9, at 51.

49. CAL. Civ. Code $\$ 232.5$ (West Supp. 1981).

50. In re Rose Lynn G., 57 Cal. App. 3d 406, 425, 129 Cal. Rptr. 338, 350 (2d Dist. 1976); In re D.L.C., 54 Cal. App. 3d 840, 850-51, 126 Cal. Rptr. 863, 868-69 (1st Dist. 1976); In re Sherman M., 39 Cal. App. 3d 40, 45, 113 Cal. Rptr. 847, 850 (2d Dist. 1974). 
fornia Civil Code section 4600 provides that before a custody petition is granted, the court must not only find that parental custody will be detrimental but also that the award to a nonparent is in the child's best interests. ${ }^{51}$ This provision has been held to be applicable to termination proceedings, ${ }^{52}$ although it has been applied in a somewhat lax manner. ${ }^{53}$ Finally, as protection against the harmful effect on the cliild of uncertainty as to his or her status, section 232.3 requires that the petition be heard within forty-five days of its filing. . $^{54}$

While traditionally the child has not been considered a party in custody cases, ${ }^{55}$ several procedures provide for the presentation of the child's interests in section 232 proceedings. Recent statutory revisions require that the child's thoughts and feelings about the proceedings and about living with his or her parents be ascertained and included in the probation report that the court must consider. ${ }^{56}$ In addition, where the child is over ten, the court is now generally required to interview him or her in chambers. ${ }^{57}$ Moreover, while the child is not required to be present, he or she has the "right" to attend. ${ }^{58}$ Perhaps more significantly, a "suitable party" - a guardian ad litem-can act to represent the child. ${ }^{59}$ The most powerful means of protecting the child's interests, however, is provided by section 237.5 , which authorizes the court to appoint counsel to represent the child's interests in the proceedings. ${ }^{60}$

51. CaL. Civ. Code $\S 4600$ (West Supp. 1981). It has been held that $\S 4600$ does not alter the judicial practice of awarding child custody to nonparents only in unusual or extreme cases. In re B.G., 11 Cal. 3d 679, 698, 523 P.2d 244, 257, 114 Cal. Rptr. 444,457 (1974). The foeus of the decision, however, has shifted from parental rights to the interests of the child. Bodenheimer, New Trends and Requirements in Adoption Law and Proposals for Legislative Change, 49 S. CAL. L. REv. 10, 28 (1975).

52. Section 4600 is apphicable to all custody proceedings. In re B.G., 11 Cal. 3d 679, 696, 523 P.2d 244, 256, 114 Cal. Rptr. 444, 456 (1974).

53. The California Supreme Court has indicated that substantial compliance with $\$ 4600$ may be inferred from the trial court's comments on the parent. In re Ricliard E., 21 Cal. 3d 349, 357, 579 P.2d 495, 499-500, 146 Cal. Rptr. 604, 609 (1978). Some courts have also lield that $\S 4600$ 's required finding of detriment can be presumed. In re Susan M., 53 Cal. App. 3d 300, 315, 125 Cal. Rptr. 707, 716 (5th Dist. 1975).

54. CAL. CIV. CoDE $§ 232.3$ (West Supp. 1981). In enacting this statute, the California legislature exphicitly recognized the "devastating effects upon a child who remains in foster care indefimitely and is shifted froin one home to another over a period of years." $1978 \mathrm{Cal}$. Stat. ch. 124.

55. Mnookin, Child-Custody Adjudication: Judicial Functions in the Face of Indeterminacy, LAW \& CONTEMP. Probs., Summer 1975, at 226.

56. 1981 Cal. Legis. Serv. 2809 (West) (to be codified at Cal. Clv. Code $\S 233$ ).

57. A younger child can also be interviewed by the court, if it is shown to be necessary. Id. at 2809 (to be codified at CAL. Crv. CODE $\$ 234$ ).

58. See id. at 2809-10 (to be codified at CAL. CIV. CODE $\$ \S 233(\mathrm{~d}), 234(\mathrm{c}), 237.5(\mathrm{a})$ ).

59. Cal. Civ. Code $\S 237$ (West Supp. 1981).

60. See supra note 8 . 
II

\section{Existing LAw of Appointment of Counsel Under SECTION 237.5}

Prior to 1961, actions to terminate parental rights were governed by the juvenile court laws of the Welfare and Institutions Code. ${ }^{61}$ But in 1960, the Governor's Special Study Commission recommended that the statutory provisions for termination be moved to the Civil Code so that they would be located with the adoption provisions. ${ }^{62}$ At the same time, two separate government studies recommended that children be granted the right to counsel in all juvenile court proceedings. ${ }^{63}$ In 1961 , these recommendations were substantially adopted. ${ }^{64}$ However, since the termination provisions were no longer in the Welfare and Institutions Code, the revision providing for counsel did not apply to thein. It was not until 1965 that section 237.5, a provision for appointment of counsel for the mimor in section 232 proceedings similar to that governing juvenile court proceedings, was added to the Civil Code. ${ }^{65}$

Section 237.5 originally was not viewed as requiring the court to consider whether separate counsel for the minor should be appoimted but as conferring a purely discretionary authority on the trial court. ${ }^{66}$ Therefore, the issue of separate representation was generally not raised in section 232 proceedings. ${ }^{67}$

This discretionary approach, however, was rejected in In re Dun-

61. Act of May 25, 1937, ch. 369, \& 701, 1937 Cal. Stat. 1005, 1032 (codified at CAL. WelF. \& INST. CODE § 701) (repealed 1961). For the history of termination of parental rights actions in California, see Comment, Proceedings to Terminate Parental Rights: Too Much or Too Little Protection for Parents?, 16 SANTA ClaRA L. REv. 337, 338 (1976).

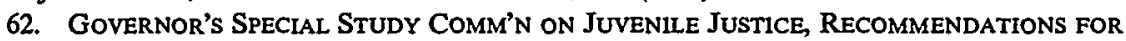
Changes in California's Juvenile Court Law, pt. 1, at 23 (1960). Adoptions are governed by CAL. CIv. CODE $\$ \$ 221-230.5$ (West 1954 \& Supp. 1981).

63. Governor's SPECIAl Study Comm'n, supra note 62, at 26; CAlifornia LAw Revision COMM'N, ReCOMmENDATION OF THE CALIFORNIA LAW ReVISION CoMmission RELATING to THE Right to Counsel and the Separation of the Delinguent from the Nondelinquent Minor In Juvenile Court Proceedings, Leg. Hist., at E-6 (1961).

64. CAL. Welf. \& INST. CODE $\S \S 633,634,700$ (added by 1961 Cal. Stat. 1616).

65. California Continuing Educ. of the Bar, Review of Selected 1965 Code legisLATION 46 (1965). Provision was made in 1961, however, for the child to be represented by a "suitable party" in § 232 proceedings. 1961 Cal. Stat. 1616, \&4 (codified at CAL. CrV. CODE $§ 237$ (West Supp. 1981)). In 1965, the remaining procedural safeguards governing juvenile proceedings were made applicable to $\$ 232$ actions. CALIfornia Continuing Educ. Of THE BAR, supra, at 46. Thus, $\S 232$ is to be "liberally construed to serve and protect the interests and welfare of the child." CAL. Crv. CODE $\S 232.5$ (West Supp. 1981). The records are to be confidential, and the hearings are to be closed. See id. $\$ \S 233.5,233.6,235.5$. In addition, the court was given discretionary authority to appoint separate counsel to represent the mimor. Id. $\$ 237.5$.

66. See In re Helen J., 31 Cal. App. 3d 238, 242, 107 Cal. Rptr. 106, 108 (2d Dist. 1973).

67. In re Dunlap, 62 Cal. App. 3d 428, 431 n.1, 133 Cal. Rptr. 310, 311 n.1 (2d Dist. 1976); telephone interview with Harry P. Drabkin, Esq., senior deputy county counsel of Stanislaus County (Nov. 9, 1981). 
lap. ${ }^{68}$ Dunlap involved a petition to free a three-year-old girl for adoption. The petition had been filed by the foster mother who had cared for the child since the age of three weeks. The natural mother contested. Upon the trial court's denial of the petition, the foster mother appealed, arguing that the child had both a constitutional and a statutory right to counsel..$^{69}$ The court of appeal reached only the latter issue and held that because the statutory scheme makes the welfare and best interests of the child central to section 232 proceedings, counsel for the minor must be appointed in these cases unless a factual showing is made at the outset indicating that independent counsel is not needed to represent adequately the child's interests. ${ }^{70}$ The burden was placed on justifying the decision not to appoint counsel because the court felt that unless the burden was so allocated, "there may well be no one involved, except in an adversary position, in the proceedings to assert the right of a child too young to assert it for himself." "11 Because the trial court made no showing that counsel was not needed, the court of appeal reversed the denial of the petition. ${ }^{72}$

The Dunlap construction of 237.5 was partially endorsed by the California Supreme Court in In re Richard $E^{73}$ In that case, the court held that although it was error not to appoint counsel for the minor in the absence of a contrary showing, the error was not cause for reversal since no miscarriage of justice was shown to have occurred. ${ }^{74}$ Thus, in one sense, Richard E. weakened Dunlap in that its miscarriage of justice standard of review makes it inuch harder to gam reversal for failure to appoint counsel. ${ }^{75}$ In another sense, however, the decision strengthened Dunlap by giving the supreme court's endorseinent to the rule that counsel for the child should be appoimted absent an affirmative showing that the child's interest would be otherwise protected. ${ }^{76}$

For courts considering appoimtment of counsel for the child, a major problein has been developing an adequate set of criteria for determining when independent counsel is in fact not necessary to protect the child's interests. Soine courts have viewed Dunlap as suggesting that

68. 62 Cal. App. 3d 428, 431-32, 439, 133 Cal. Rptr. 310, 311-12, 316 (2d Dist. 1976).

69. Id. at 437,133 Cal. Rptr. at 315.

70. Id. at 431-32, 439, 133 Cal. Rptr. at 311-12, 316.

71. Id. at 439,133 Cal. Rptr. at 316.

72. Id. at 432,133 Cal. Rptr. at 312.

73. 21 Cal. 3d 349, 579 P.2d 495, 146 Cal. Rptr. 604 (1978). Richard E. was an appeal from a decision freeing a seven-and-one-half-year-old boy from the custody and control of a father who was in jail for bank robbery.

74. Id. at 354-56, 579 P.2d at 499, 146 Cal. Rptr. at 608.

75. The two cases have therefore been viewed as inconsistent. In re Jacqueline H., 94 Cal. App. 3d 808, 814, 156 Cal. Rptr. 765,768 (2d Dist. 1979). See Singer \& Shipper, The Child's Right to Independent Counsel in Custody Hearings, 5 LAW \& PsYchOLOGY Rev. 51, 63-65 (1979).

76. 21 Cal. 3d at 355, 579 P.2d at 499, 146 Cal. Rptr. at 608. 
separate counsel is required primarily when the petitioner is a private party. ${ }^{77}$ Other courts have read Dunlap to require also that counsel be appointed whenever county counsel cannot adequately represent the child's interests due to a conflict. ${ }^{78}$ One appellate case suggests that an additional consideration should be the child's ability to express an intelligent preference. ${ }^{79}$ The criteria that have been perhaps most frequently utilized, however, are based on a Dunlap footnote. ${ }^{80}$ In that footnote, the court indicated that two factors that might be relevant are whether the child is a dependent and whether the petitioner is a state agency, but the court carefully refrained from formulating a substantive test. ${ }^{81}$ The shortcomings of relying on these two factors were shown in In re Christina $L .{ }^{82}$ where the court of appeal held that even though the child was a dependent and the state was the petitioner, reversal was warranted because county counsel had failed to represent the child's interests. ${ }^{83}$ The court's decision thus makes it clear that the factors mentioned in the Dunlap footnote do not adequately determine when independent counsel for the child is not needed.

Not only have the courts had difficulty formulating criteria to determine when it is appropriate to appoint counsel for the child, they have also been unable to arrive at a consensus as to the role counsel should play once appointed. ${ }^{84}$ Soine courts have expressed doubts as to

77. In re Jacqueline H., 94 Cal. App. 3d 808, 814, 156 Cal. Rptr. 765, 768 (2d Dist. 1979).

78. The court pointed out in Dunlap that "[t]here is some question whether deputy county counsel could here act for anyone other than the county without a conflict of interest. . . . Delay occasioned by excessive social worker case loads has allowed a situation to develop that will be unnecessarily traunatic to one or more of the parties." 62 Cal. App. 3d at 440 n.3, 133 Cal. Rptr. at 317 n.3. This reasoning has been viewed as central in distinguishing Dunlap. See In re Marcos S., 73 Cal. App. 3d 768, 780, 140 Cal. Rptr. 912.918 (2d Dist. 1977); Guardianship of Baby Boy M., 66 Cal. App. 3d 254, 268 n.10, 135 Cal. Rptr. 866, 874 n.10 (4th Dist. 1977). See also Senate Comm. on Judiciary, Analysis of A.B. 344, at 4 (Mar. 4, 1981).

79. In re Jack H., 106 Cal. App. 3d 257, 269-70, 165 Cal. Rptr. 646, 654 (4th Dist. 1980).

80. A number of courts have used the Dunlap factors to justify denial of counsel. See In re Christina L., 118 Cal. App. 3d 737, 747, 173 Cal. Rptr. 722, $727-28$ (2d Dist. 1981); In re Heidi T., 87 Cal. App. 3d 864, 876, 151 Cal. Rptr. 263, 269 (1st Dist. 1978); In re Marcos S., 73 Cal. App. 3d 768, 780, 140 Cal. Rptr. 912, 918 (2d Dist. 1977).

81. In re Dunlap, 62 Cal. App. 3d at 439 n.2, 133 Cal Rptr. at 316 n.2.

82. 118 Cal. App. 3d 737, 173 Cal. Rptr. 722 (2d Dist. 1981).

83. Id. at 747-48, 173 Cal. Rptr. at 727-28. By permitting reversal, Christina $L$. now provides a remedy for failure to represent the child's interests. However, this is not a wholly satisfactory means of protecting those interests because the delays and prolonged insecurity of appellate litigation are at odds with the child's interest in security and rapid placement. See supra notes 44,48 , 54 and accompanying text. Moreover, reversal of a custody order on appeal would be a traumatic disruption to the child. See Bodenheimer, supra note 53, at 90.

84. This confusion may stem in part from the fact that when the child's right to counsel is raised on appeal, it is not asserted by the child but is usually raised by a losing parent. See, e.g., In re Richard E., 21 Cal. 3d at 355, 579 P.2d at 499, 146 Cal. Rptr. at 608; In re Heidi T., 87 Cal. App. 3d 864, 876-77, 151 Cal. Rptr. 263, 269 (1st Dist. 1978). The confusion of some appointed counsel as to what is expected of then is an additional problem. Drabkin interview, supra note 67; Snyder interview, supra note 4. 
the ability of independent counsel to play any useful role at all, on the theory that in arguing about parental "fitness" the parties will bring in evidence regarding the child's best interests. ${ }^{85}$ Other courts have expressed doubts as to the utility of counsel when the child is very young. ${ }^{86}$ While some positive suggestions have been inade, ranging from simply representing the child's feelings ${ }^{87}$ and suppleinenting the probation report ${ }^{88}$ to actively advocating the child's interests through testimony and arguinent, ${ }^{89}$ the courts' uncertainty as to counsel's function under section 237.5 has contributed to the confusion surrounding its application. ${ }^{90}$

In 1981, the California legislature reenacted section 237.5, clarifying its provision but leaving the case law unchanged. ${ }^{91}$ As reenacted, the statute unmistakably requires that the trial court consider the need for separate counsel for the child at the outset of all section 232 cases. ${ }^{92}$

85. In re Richard E., 21 Cal. 3d at 354, 579 P.2d at 498, 146 Cal. Rptr. at 607; In re Heidi T., 87 Cal. App. 3d 864, 876-77, 151 Cal. Rptr. 263, 269 (1st Dist. 1978). In fact, however, the dispute may center on a number of interests and issues that are extraneous to the child's intcrests. In re Richard E., 21 Cal. 3d at 360, 579 P.2d at 502-03, 146 Cal. Rptr. at $611-12$ (Bird, C.J., dissenting).

86. Compare In re Marcos S., 73 Cal. App. 3d 768, 779, 140 Cal. Rptr. 912, 917-18 (2d Dist. 1977) with In re Dunlap, 62 Cal. App. 3d at 438-39, 133 Cal. Rptr. at 315-16.

87. In re Richard E., 21 Cal. 3d at 361, 579 P.2d at 503, 146 Cal. Rptr. at 612 (Bird, C.J., dissenting); In re Jack H., 106 Cal. App. 3d 257, 269, 165 Cal. Rptr. 646, 653-54 (4th Dist. 1980).

88. In re Richard E., 21 Cal. 3d at 361, 579 P.2d at 503, 146 Cal. Rptr. at 612 (Bird, C.J., dissenting).

89. In re Geoffrey G., 98 Cal. App. 3d 412, 426, 159 Cal. Rptr. 460, 468 (5th Dist. 1979) (Hopper, J., dissenting).

90. Moreover, some informed observers have been unenthusiastic about the performance of appointed counsel in these and similar proceedings. Bodenheimer, supra note 53, at 101; Solender, The Guardian Ad Litem: A Valuable Representative or an Illusory Safeguard?, 7 TEx. TECH L. Rev. 619, 636-39 (1976); Dembitz, Book Review, 83 YALE L.J. 1304 (1974); Brandt interview, supra note 3; Drabkin interview, supra note 67. But see Note, Lawyering for the Clild: Principles of Representation in Custody and Visitation Disputes Arising from Divorce, 87 YALE L.J. 1126, 1185 (1978).

Satisfactory results have been reported, however, when performance guidelines are given to counsel. Solender, supra, at 635. See, e.g., Holn, The Child Advocate in Private Custody Disputes: The Wisconsin Experience, 16 J. FAM. L. 739, 743 (1977-78). Interviews with judges and attorneys in the San Francisco Bay area (who have asked not to be quoted) held during the fall of 1981 indicate that courts find separate counsel most effective when attorneys experienced in the representation of children or in family law are appoimted.

91. See supra note 8. Existing case law requiring appointment of counsel unless the minor's interests are adequately represented by county counsel was impliedly approved. See Assembly Comm. on Judiciary, Analysis of A.B. 344 as amended Mar. 3, 1981, at 4 (1981); Senate Comm. on Judiciary, Analysis of A.B. 344 as amended June 22, 1981, at 4 (1981). The purpose of the revisions was to remove the implication under former $\$ 237.5$ that the child was required to be present at the liearing. Drabkin interview, supra note 67; Assembly Office of Research Digest, A.B. 344, at 3 (Sept. 1, 1981). In his statement to the Senate Committee on Judiciary, Assemblyman John E. Thurman stated that "the most important [procedural improvement in the bill] is clarifying the court's ability to have a child represented, rather than plysically present, when the courts hear arguments as to the biological parents' unsuitability for contimued custody of the child." Statement of Aug. 20, 1981.

92. Senate Comm. on Judiciary, Analysis of A.B. 344 as amended June 8, 1981, at 3 (1981); 
This revision indicates the legislature's increasing sensitivity to the need to protect the child's interests in termination proceedings ${ }^{33}$ and should result in courts routinely considering appointment of counsel. It does not, however, answer the two questions that have plagued the courts in applying section 237.5: (1) when should separate counsel for the child be appointed? and (2) what role should separate counsel play if appointed? Parts III and IV propose answers to these questions.

\section{III}

\section{GUIDELINES For APPoINTING COUNSEL}

There are several possible grounds on which to base the decision to appoint separate counsel for the child. Part III addresses two of these: first, analyzing appointment of counsel based on the need to protect the child's interests, and second, suggesting that counsel should also be appointed whenever the child so requests.

\section{A. When Needed to Protect the Interests of the Child}

According to the rule endorsed by the California Supreine Court, separate counsel for the child should be appointed absent an affirmative showing that the child's interests would otherwise be protected. ${ }^{94}$ The question arising under this rule is what interests of the child are to be protected. Simce the purpose of authorizing appointment of counsel is to assure that otherwise unprotected interests receive protection,,$^{95}$ the relevant interests clearly are those that counsel for the child would normally act to protect. These interests are of two types: while counsel for

Senate Republican Caucus Bill Digest, A.B. 344, at 1 (1981). Former \$ 237.5 did not expressly require this consideration but provided in pertinent part:

At the beginning of the proceeding on a petition filed pursuant to this cliapter, the judge. . . sliall advise the minor and the parents, if present, of the right of each of them to have counsel present. The court may appoint counsel to represent the minor whether or not the minor is able to afford counsel.

CAL. CIv. CoDE $\S 237.5$ (West Supp. 1981). Compare $\S 237.5$ as reenacted, providing that the court "sliall consider whether the interests of the minor require the appointment of counsel." See supra note 8.

93. The legislature has recognized that the child may require his or her own representative in numerous proceedings where child custody is in issue. There are now provisions for appointment of separate counsel for the minor in dependency proceedings, CAL. WELF. \& INST. CODE $\$ \& 317$, 349 (West Supp. 1981); child abuse proceedings, Id. \& 318; guardianship proceedings, CAL. ProB. CODE $\$ 1470$ (West 1981); and divorce proceedings, CAL. CIv. CODE $\$ 4606$ (West Supp. 1981). In demonstration counties, separate counsel for the minor must be appointed at all stages of proceedings involving the minor, including termination of parental rights. CAL. WELF. \& INST. CODE $\S 318.5$ (West Supp. 1981). This provision has not, lowever, been included in the Senate Bill that would extend the demonstration county provisions statewide, and the office of Senator Presley las announced that the provision will not be introduced. Telephone interview with Rita Gordon, consultant to the Senate Comin. on Children and Youth (Feb. 4, 1981).

94. See supra note 76 and accompanying text.

95. See supra notes 8,93 . 
the child must always act to protect his or her chent's best interests, ${ }^{96}$ counsel is also expected to represent the child's professed desires, if the child is old enough to articulate them. ${ }^{97}$ Thus, protcction inust be given to both the child's best and professed interests. ${ }^{98}$

The supreme court's rule also raises the question of the type of protection the child's interests must receive. Again, the answer hes in the anticipated effects of appointment of counsel. Since the rule implies that unprotected interests become protected if counsel is appointed to represent them, the protection must be of the type that can be provided by representation of counsel. This does not necessarily mean, however, that separate counsel inust be appointed unless the child's interests are otherwise formally represented by counsel. Rather, as the supreme court's discussion in Richard $E$. indicates, it should be sufficient that the court can be assured that substantially everything will be done to protect the child's interests which could be expected to be done if separate counsel werc appointed.99

What counsel for the child is expected to do to protect the child's best and profcssed interests can be described as the advocacy of those

96. See ABA Code of Professional Responsibility EC 7-9, 7-12 (1978).

97. See id. at EC 7-7, 7-8. Legislative revisions of $\& 232$ proceedings now inake it clear that the child's wishes are to be given serious weight. See supra notes 56-57 and accompanying text. See also CAL Civ. Code $\S 4600$ (West Supp. 1981), which requires the court to give due weight to the child's wishes if he or she has the capacity to form an intelligent preference as to custody. Moreover, as the child's wishes may alone be sufficient reason for appointing counsel, see In re Jack H., 106 Cal. App. 3d 257, 269, 165 Cal. Rptr. 646, 653-54 (4th Dist. 1980); Senate Comm. on Judiciary, Analysis of A.B. 344 as amended June 22, 1981, at 3 (1981), counsel is clearly expected to assert the child's preference. Furthermore, the legislature may have impliedly approved the practice of appointing counsel for the child unless the child is "too young to communicate." Senate Comm. on Judiciary, supra, at 3 (quoting the source of the bill for this contention).

98. It should be noted that "best interests" is not the substantive test for whether termination will be granted or denied, although these inust be considered if the petition is granted. See supra notes 2, 16-19, 53 and accompanying text. Although the concept of "best interests of the child" has been subject to searching criticisn, see, e.g., BEYOND THE BEST INTERESTS, supra note 9, at 5364; Wald, supra note 4, at 649-50, the defects of vagueness and subjectivity that have marked "best interests" tests for criticism are largely cured in $\S 232$ cases, as the legislature has explicitly defined what the child's best interests are-entering a secure and stable home, if one is lacking, as rapidly as possible. See supra notes 37,54 and accompanying text. The child inay, however, have interests based on an attachinent to natural parents or family that will not be served by being freed for adoption. See supra notes $45-47$ and accompanying text. By requiring that the child's thoughts and feelings be explored, see supra notes 56-57 and accompanying text, the legislature has also made possible the advocacy of the child's own desires should they conflict with the apparent "best interests" in a permanent home. Therefore, complete protectiou of the child's interests entails advocacy both of the broadly perceived best interest in stable placement and of those interests that are experienced and expressed by the child.

The importance of bringing both kinds of interests before the court has been recognized in the proposed revisions to $\S 232$, which provides that in all termination proceedings, "the court shall consider the wishes of the child and shall act in the best interests of the child." S.B. 14, discussed supra note 7.

99. See In re Richard E., 21 Cal. 3d at 354-56, 579 P.2d at 499, 146 Cal. Rptr. at 608. 
interests. Advocacy of the child's interests in part requires that counsel fully inform the court of the child's interests at all appropriate times. Unless the court is so informed, it cannot take the child's interests into consideration in the course of the proceedings nor can it be guided by thein in reaching a decision. Advocacy of the child's interests, however, goes beyond merely providing the court with information. Much of the value of advocacy lies in advocating positions consistent with the child's interests. While the expected emphasis is on advocatimg the desired disposition, advocacy also entails protecting those interests of the child that are implicated by subsidiary issues, such as the rapidity of the proceedings. ${ }^{100}$

Because section 232 cases may raise complex issues ${ }^{101}$ and are litigated in a traditional adversary inanner, ${ }^{102}$ protection of the child's interests requires the presence of a skilled advocate, who is able to pursue them at every stage in the process. ${ }^{103}$ It is thus clear that advocacy of the child's imterests requires counsel. However, separate counsel is not necessarily required; if it can be shown that counsel for one of the participants can be relied on to advocate both the child's best and professed interests, appointment of separate counsel is not necessary. Thus, in order to determine whether separate counsel inust be appointed, the court should assess the ability of counsel who are already involved to advocate the child's interests.

\section{Parents' Counsel as Advocate of the Child's Interests}

Parents' counsel is ill-suited to advocate the child's interests. While the law generally assumes that parents are proper representatives of their child's interests, ${ }^{104}$ this assumption is undermined where

100. See supra note 44 and accompanying text.

101. See, eg., In re Angelia P., 28 Cal. 3d 908, 623 P.2d 198, 171 Cal. Rptr. 637 (1981) (court required to determine the appropriate burden of proof under $\$ 232$ ); In re Carmaleta B., 21 Cal. 3d 482, 579 P.2d 514, 146 Cal. Rptr. 623 (1978) (sufficiency of evidence of mental illness, cruelty, and neglect required under § 232); In re Virgil S., 5 Civ. No. 5738 (5th Dist. Oct. 8, 1981) (multiple parties seeking custody).

102. See Carrieri \& Marawski, Proposing Standards for Child Custody: The Proceedings, the Role of the Agency, and the Best Interests of the Child, 6 FordHAM URB. L.J. 185 (1978). For a summary of the testimony at a $\$ 232$ hearing, see In re Christina L., 118 Cal. App. 3d 737, 741-43, 173 Cal. Rptr. 722, 724-25 (2d Dist. 1981). Unlike typical civil proceedings, however, $\$ 232$ hearings are closed to the public, and the records are confidential. CAL. Civ. CODE $§ \S 233.5,235.5$ (West Supp. 1981).

103. The petition frequently will not be contested. A study of one California county showed that only eight out of the forty petitions filed during the period covered were contested. Mnookin, supra note 55, at 276. Even uncontested petitions may require skilled advocacy, as the evidence supporting petitioner's allegation must meet the clear and convincing standard. See supra note 17 and accompanying text. Conversely, if the child is opposed to termination, advocacy of this position would be necessary as no one involved would have any reason to assert this preference.

104. BEYOND THE BEST INTERESTS, supra note 9, at 65-66. A recent articulation of the basis for the presumption, which can be overcome, suggests that natural parents represent the child 
the proceedings are to terminate parental rights. ${ }^{105}$ Because the parents are charged with being generally unwilling or unable to protect the child's welfare, they cannot be assumed to be acting to protect the child's interests in the proceedings. ${ }^{106}$

Moreover, parents faced with these proceedings have their own interests to protect. In addition to having an interest in preserving their ties to the child, ${ }^{107}$ they have an interest in not being held inadequate parents. ${ }^{108}$ Since unlike other parties, the natural parents carry no burden of persuasion, ${ }^{109}$ counsel for the parents may act to protect these interests by simply contesting the sufficiency of the evidence ${ }^{110}$ or by alleging that the parents were denied proper treatment by the state agencies involved. ${ }^{111}$ While these positions inay adequately protect the parents' interests, they have no bearing on the interests of the child. It is thus unlikely that counsel for the parents will be able to advocate effectively the child's interests while safeguarding those of his or her primary chents. The legislature appears to have recognized this problem in declaring that appointed counsel cannot jointly represent the parents and the child. ${ }^{112}$ Counsel for the parents therefore should probably never be rehed on to advocate the interests of the child.

\section{State's Counsel as Advocate of the Child's Interests}

Counsel for the state is perhaps uniquely able to advocate the child's interests. Since the dominant interest of the state is its interest

because the ongoing parent-child relationship, in order to flourish, requires a high degree of autonomy and authority on the part of the parent. J. GoLDSTEIN, A. FREUD \& A. SOLNIT, BEFORE THE BEST INTERESTS OF THE CHILD 111-17 (1979). When a $\$ 232$ petition is brought, however, this relationship has generally been seriously attenuated. See supra note 4.

105. See In re Angelia P., 28 Cal. 3d 908, 919, 623 P.2d 198, 204, 171 Cal. Rptr. 637, 643 (1981).

106. According to one court, the inability of a parent's attorney to represent the child effectively stems from the fact that a termination proceeding questions the parent's "fitness," and therefore his or her counsel is "bound by professional ethics to put forth his best efforts to refute the clrarge of unfitness and to preserve for his client the parent-child relationship . . . This duty is not unodified or diminished in any way by any obligation to protect the 'best interests' of the child involved." State ex rel. Juvenile Dep't of Multnomah County v. Wade, 19 Or. App. 314, -, 527 P.2d 753, 757 (1974), overruled, In re D., 24 Or. App. 601, -, 547 P.2d 175, 181 (1976).

107. See supra text accompanying notes 11-13.

108. See supra note 14 and accompanying text.

109. See supra note 53 and text accompanying notes 16-19.

110. See, e.g., In re Carmaleta B., 21 Cal. 3d 482, 579 P.2d 514, 146 Cal. Rptr. 623 (1978); In re Christina L., 118 Cal. App. 3d 737, 173 Cal. Rptr. 722 (2d Dist. 1981). The evidence must, by a recent California Supreme Court decision, meet the clear and convincing standard. See supra note 17 and accoinpanying text.

111. It is a common trial strategy to allege that the state agency has been unfair or unjust in its dealings with the parent. Carrieri \& Marawski, supra note 102, at 192; Hardm, When a Parent is Unfit, FAM. ADVOCATE, Fall 1981, at 9, 14.

112. Section $\mathbf{2 3 7 . 5}$ as reenacted specifically forbids joint representation of the minor and a parent. See supra note 8. 
in protecting the child, ${ }^{113}$ state's counsel generally will be unavoidably advocating the child's imterests. ${ }^{114}$ Although it seems that counsel for the state can usually be rehed on to advocate the interests of the child, there may be cases im which state's counsel cannot be relied on to serve that function either because it appears unlikely that state's counsel will attempt to advocate adequately a significant interest of the child or because it appears that even though state's counsel will attempt to advocate such an interest, it is ill-prepared to do so. ${ }^{115}$

\section{a. When Unlikely to Advocate Vigorously a Significant Interest}

Althougl in general the state's interest is in protecting the child's interests, the legislature has stated that more specifically the state's interest is in providing the child with a secure and stable home. ${ }^{116}$ Thus, if the state's conception of what this interest requires conflicts with other significant interests of the child, either best or professed, state's counsel will be unlikely to be an adequate advocate of those interests. Such a conflict may occur when the child has a deep einotional attachinent to his or lier parents even though they are unable to provide a secure and stable hoine. Children can be so deeply attached to their parents, despite their inadequacies, that severing the relation is more harmful to the child than leaving thein with the parents. ${ }^{117}$ Even where a child wishes to be adopted, he or she may also wish to continue contact with a parent, or another family neinber, to whoin there is a strong attachment. ${ }^{118}$ A similar situation may arise where the child has a

113. See supra notes $34-37$ and accompanying text. Concern has been expressed that the growing demand for adoptable children may cause state adoption agencies to push to the limit laws which authorize freeing children from parents. See Bodenheimer, supra note 53, at 15. A study of one county's mechanism for initiating adoption related procedures revealed, however, that reluctance to move in appropriate cases is more of a problem than is excessive zeal. Mnookin, supra note 55, at 275-77.

114. County counsel most commonly represents the state's interests in $\$ 232$ cases. Senate Comm. on Judiciary, Analysis of A.B. 344 as amended Mar. 9, 1981, at 3 (1981).

115. It has been held an error to presume that county counsel represents the child's interest. In re Jack H., 106 Cal. App. 3d 257, 269-70, 165 Cal. Rptr. 646, 654 (4th Dist. 1980).

116. See supra note 37 and accompanying text.

117. See supra note 45.

“'Although a home environment may appear deficient when measured by dommant socioeconomic standards, interposition by the powerful arm of the public authorities may lead to worse alternatives.' "In re Jack H., 106 Cal. App. 3d 257, 263, 165 Cal. Rptr. 646, 650 (4th Dist. 1980) (quoting In re Raya, 255 Cal. App. 2d 260, 265, 63 Cal. Rptr. 252, 255 (3d Dist. 1967)); see Ardvagh, Califormia Civil Code Section 4606: Separate Representation for Children in Dissolution Custody Proceedings, 14 U.S.F.L. REv. 571, 579 (1980); see generally Dembitz, supra note 90, at 1307-10.

118. "A child may even benefit from having two sets of parents." Wald, supra note 4, at 672. See also In re Angehia P., 28 Cal. 3d 908, 931, 623 P.2d 198, 211, 171 Cal. Rptr. 637, 650-51 (1981) (Bird, C.J., concurring and dissenting) (arguing that the child had an interest in continued contact with her mother, who probably could not be granted custody due to the presence of an abusing father). In denonstration counties, termination of parental rights is denied where parents have 
strong attachment to his or her de facto parents, but because of its concern with the de facto parents' ability to provide a secure and stable home ${ }^{119}$ or because of the de facto parents' failure to meet the agency's adoption standards, ${ }^{120}$ the state seeks to arrange other adoptive placement. ${ }^{121}$ When termination is sought in such circumstances, separate counsel should be appointed to protect the child's interests im the threatened relationship. ${ }^{122}$

Separate counsel will also be needed if it appears that the state is acting to terminate the parents' rights out of some interest in addition to their concern for the child's welfare. One notable situation in which this may occur is where the propriety of the state social worker's conduct is in question ${ }^{123}$ or a state agency may have violated statutory or internal regulations or the parents' due process rights. ${ }^{124}$ In such a situation, counsel for the state may not be an effective advocate of the child's interests either because counsel may be forced to concentrate on

maintained a "close family relationship with the minor through regular visitation and contact and the minor would benefit from a continued relationship . . . or a minor 14 years . . . or older objects to termination." CAL. WeLF. \& INST. CODE $\S 366.5$ (West Supp. 1980). This provision is mcluded in S.B. 14. See supra note 7.

1I9. De facto parents who are willing to provide long term care for the child may not wish to adopt formally. Wald, supra note 4, at 697.

120. See, e.g., Katzoff v. Superior Court, 54 Cal. App. 3d 1079, 127 Cal. Rptr. 178 (1st Dist. 1976) (agency opposed cross-racial foster parent adoption).

121. See, e.g., In re Richard E., 21 Cal. 3d 349, 358, 579 P.2d 495, 501, 146 Cal. Rptr. 604, 610 (1978) (child had been removed from foster home in which he was prospering, and it was unclear whether the foster parents would adopt him upon termination). The problem of such removals should be a decreasing one, however, as state opposition to foster parent adoption, which once was traditional, has largely disappeared in California. Bodenheimer, supra note 53, at 37 . See also infra note 122. Furthermore, termination of parental rights where adoption is not possible would be prevented by S.B. 14. See supra note 7.

122. In such cases, guardianship is a possible alternative. Bodenheimer, supra note 53, at 42. See generally Taylor, Guardianship or "Permanent Placement" of Children, 54 CALIF. L. REV. 741 (1966). In addition, courts may be persuaded to take account of the desire of siblings not to be separated. In re James M., 65 Cal. App. 3d 254, 135 Cal. Rptr. 222 (4th Dist. 1976) (children wished to remain together, probation report recommended demal of the petition).

In the demonstration counties, foster parents inust be considered in permanent planning for the child, and removal will be prevented where the child is strongly attached to them, even if adoption is not offered, as long as stability can be provided. See supra note 7. A similar resolution could be proposed by counsel for the child in the $\$ 232$ proceedings.

123. It is possible that in some cases, a personality clash between the social worker and the parent will give rise to an inference that the petition is being brought as a result of this strife, raising a conflict of interest. Parent-social worker relationships are often strained. Interview with Paul Lewis, Esq., Legal Services for Children, Inc., in San Francisco (Dec. 24, 1981). See, e.g., In re Jacqueline H., 94 Cal. App. 3d 808, 811-12, 156 Cal. Rptr. 765, 766-67 (2d Dist. 1979).

124. See, e.g., In re Antomio F., 78 Cal. App. 3d 440, 144 Cal. Rptr. 466 (4th Dist. 1978) (due process denied mother by insufficient notice); In re George G., 68 Cal. App. 3d 146, 137 Cal. Rptr. 201 (2d Dist. 1977) (failure to get proper jurisdiction over child in prior proceedings); In re Dunlap, 62 Cal. App. 3d 428, 440, 133 Cal. Rptr. 310, 316-17 (2d Dist. 1976) (failure to return child to mother after return was agreed to by social worker). 
defending the state's conduct ${ }^{125}$ or because the state's "unclean hands" may prejudice the court against its positions. ${ }^{126}$

In addition, a special interest of the child that the state inay fail to protect adequately is the interest in having the proceedings concluded as quickly as possible. ${ }^{127}$ The longer the uncertainty about his or her status, the greater the harm to the child. ${ }^{128}$ Therefore, if state's counsel appears not to be proceeding with due speed, for exainple, if he or she seeks or concurs repeatedly in continuances, ${ }^{129}$ appointment of separate counsel may be called for.

\section{b. When Improperly Prepared to Advocate a Significant Interest}

In determining where the child's interests lie, courts generally look for information about the child's enotional and physical makeup, ${ }^{130}$ the nature of the child's relationship with his or her parents, ${ }^{131}$ and the child's preference in the proceedings. ${ }^{132}$ In addition, courts inay look at post-termination plans for stable placeinent, which arguably must be

125. See In re Dunlap, 62 Cal. App. 3d 428, 440, 133 Cal. Rptr. 310, 317 (2d Dist. 1976).

126. See Beyond the BeSt INTERESTS, supra note 9 at 79; Note, $A$ Damages Remedy for Abuses by Child Protection Workers, 90 YALE L.J. 681, 681 (1981).

127. See Note, Termination of Parental Rights-Suggested Reforms and Responses, $16 \mathrm{~J}$. FAM. L. 239, 246 (1977-78). Moreover, the child's interests require that the proceedings be kept free of any errors that might encourage an appeal, with its attendant harms to the child. See supra note 83.

128. See supra notes 44,48 and accompanying text.

129. Continuances for good cause are available under $C_{A L}$. Clv. COdE $\$ 232.3$ (West Supp. 1981); see supra note 54.

130. See, e.g., In re Angelia P., 28 Cal. 3d 908, 913, 623 P.2d 198, 200, 171 Cal. Rptr. 637, 63940 (1981) (Bird, C.J. concurring and dissenting); In re Richard E., 21 Cal. 3d 349, 361, 579 P.2d 495, 503, 146 Cal. Rptr. 604, 612 (1978); In re Sarah H., 106 Cal. App. 3d 326, 330, 165 Cal. Rptr. 61, 63 (3d Dist. 1980); In re Marcos S., 73 Cal. App. 3d 768, 775, 140 Cal. Rptr. 912 , 915 (2d Dist. 1977).

131. In re George G., 68 Cal. App. 3d 146, 154, 137 Cal. Rptr. 201, 205-06 (2d Dist. 1977) (evidence was also relevant to intent to abandon). See In re Angeha P., $28 \mathrm{Cal} .3 \mathrm{~d}$ 908, 931, 623 P.2d 198, 211, 171 Cal. Rptr. 637, 651 (1981) (Bird, C.J., concurring and dissenting); In re Richard E., $21 \mathrm{Cal}$. 3d at 361, 579 P.2d at 503, 146 Cal. Rptr. at 612 (Bird, C.J., dissenting); In re Jack H., $106 \mathrm{Cal}$. App. 3d at 269, $165 \mathrm{Cal}$. Rptr. at 654. See also supra note 67 and accompanying text.

The need for information about the impact of severance on the child is recognized in $\S 233$ as reenacted, which provides that the child's attitude toward his or her parents and towards hiving with them be noted in the report. 1981 Cal. Legis. Serv. 2809 (West) (to be codified at Cal. Crv. CODE \& 233). The efficacy of this provision depends, of course, on the child's ability to articulate his or her feelings. More objective facts should also be presented because this inay be an unduly burdensome demand to place on the child. See Wald, supra note 4, at 697.

132. In re Heidi T., 87 Cal. App. 3d 864, 877, 151 Cal. Rptr. 263, 269 (1st Dist. 1978) (children's preference testifed to indirectly); Guardianship of Marino, 30 Cal. App. 3d 952, 955, 106 Cal. Rptr. 655, 656 (2d Dist. 1973) (child insisted on conferring with the judge). But see In re Richard E., 2l Cal. 3d 349, 361, 579 P.2d 495, 503, 146 Cal. Rpr. 604, 612 (1978) (Bird, C.J., dissentimg); In re Jack H., 106 Cal. App. 3d 257, 269, 165 Cal. Rptr. 646, 654 (4th Dist. 1980); In re Dunlap, 62 Cal. App. 3d 428, 440-4l, 133 Cal. Rptr. 310, 317 (2d Dist. 1976). The child’s preference inust now be included in the probation report under $\S 233$. 
considered in light of the purpose of the proceedings. ${ }^{133}$ If the state is to advocate adequately the child's interests, it inust be prepared to provide the court with this information. ${ }^{134}$ The state is presently required to investigate the child's circumstances and his or her feelings about the termination of parental rights and then to make a recommendation to the court. ${ }^{135}$ This investigation, however, nay be carried out by a state agency that has had no prior involveinent with the child ${ }^{136}$ and inay not contain all of the facts courts consider relevant to the child's interests. ${ }^{137}$ The state's position inay therefore lack an adequate foundation regarding the child's interests unless it conducts a supplementary inves-

133. In most cases where these plans are offered, longtime foster or de facto parents seek to adopt the child. See, e.g., Adoption of D.S.C., 93 Cal. App. 3d 14, 20, 155 Cal. Rptr. 406, 409 (4th Dist. 1979); In re Heidi T., 87 Cal. App. 3d 864, 874, 151 Cal. Rptr. 263, 268 (1st Dist. 1978); In re Marcos S., 73 Cal. App. 3d 768, 775-76, 140 Cal. Rptr. 912, 915-16 (2d Dist. 1977); In re Rose Lynn G., 57 Cal. App. 3d 406, 415, 129 Cal. Rptr. 338, 343 (2d Dist. 1976). But cf. In re Angelia P., 28 Cal. 3d 908, 932, 623 P.2d 198, 211-12, 171 Cal. Rptr. 637, 651-52 (1981) (unclear whether there were prospects of adoption); In re Richard E., 21 Cal. 3d 349, 358, 579 P.2d 495, 501, 146 Cal. Rptr. 604, 610 (1978) (same). In the demonstration counties, a permanent plan must be submitted before termination of parental rights is considered. CAL. WELF. \& INST. CODE $\$ 366.5$ (West Supp. 1981).

It is certainly arguable that a permanent plan must be presented under CAL. Civ. CoDe $\$ 4600$ (West Supp. 1981) as well, as it is difficult to see how a court can determine that the award of custody to petitioner is in the child's best interests without knowing what petitioner will do to provide the child with security. See Wald, supra note 4, at 673-74.

134. Section 232 proceedings are to be construed so as to serve the welfare and best interests of the minor and to provide him or her with stable placement. In addition, parental custody cannot be terminated unless such custody would be detrimental to the child and an award to nonparents would be in the child's best interests. CAL. Civ. CoDE $\$ \S 232.5,232.6,4600$ (West Supp. 1981). All of these provisions require knowledge about the child's present state, and an informed prediction about his or her future. In the present state of knowledge on child development, it is extremely difficult to predict what will be best for a child. See BeYond THE BeST INTERESTS, supra note 9, at 49-52. This difficulty is certainly compounded if the court is not supplied with adequate information about the child's present condition.

135. See supra note 22 .

136. In In re Richard E., 21 Cal. 3d 349, 358, 579 P.2d 495, 501, 146 Cal. Rptr. 604,610 (1978) (Bird, C.J., dissenting), the dissent pointed out that "the preparer of the probation report had not interviewed either Richard or his father, but apparently compiled the report from the files of various county agencies and the federal Bureau of Prisons." See also In re Heidi T., 87 Cal. App. 3d 864, 875, 151 Cal. Rptr. 263, 268 (1st Dist. 1978) (appellate court recognized "technical" deffciency of probation report consisting of "incorporation of copies of the official juvenile court records relating to the children's dependency status" but found abundant independent evidence had been presented); In re George G., 68 Cal. App. 3d 146, 150, 137 Cal. Rptr. 201, 203 (2d Dist. 1977) (probation officer testified that the source of his information concerning the minors and the parents was based on paraphrased records of Department of Social Services).

137. In re Richard E., 21 Cal. 3d 349, 358, 361-62, 579 P.2d 495, 501, 503, 146 Cal. Rptr. 604, 610,612 (1978) (Bird, C.J., dissenting) (no evidence about the child's einotional makeup, plans for permanent placement, his attachment to his father and brothers, or his own preference); In re Jack H., 106 Cal. App. 3d 257, 269, 165 Cal. Rptr. 646, 654 (4th Dist. 1980) (no evidence about the child's preference); In re Dunlap, 62 Cal. App. 3d 428, 436, 440-41, 133 Cal. Rptr. 310, 314, 317 (2d Dist. 1976) (probation report not offered in evidence although it contained evidence of the child's preference). 
tigation. If the state appears to lack such a foundation, ${ }^{138}$ it cannot be rehied on to advocate adequately the child's interests and separate counsel should be appointed.

Similarly, unless the state has prepared an ainple trial presentation on the child's interests, separate counsel is needed. There is no requirement similar to the state-prepared report regarding the presentation of testimonial evidence concerning the child at trial ${ }^{139}$ and, in some cases, little or none is produced. ${ }^{140}$ Courts typically expect the parties inost affected by a dispute to participate in the adjudicatory process, ${ }^{141}$ and as allegations by the petitioner and the parents are often hard fought, ${ }^{142}$ courts may focus solely on the interests of the adult contestants. Unless there is evidence and argument concerning the child's interests at trial, they will be spoken for only by a written report, prepared by a nonlawyer. In an adversary setting, this level of input may not effectively safeguard them. ${ }^{143}$ Thus, unless it appears that the state has not only fully informed itself of the child's interests but is also well prepared to advocate them vigorously in the hearing, separate counsel should be appointed.

\section{De Facto Parents' Counsel as Advocate of the Child's Interests}

Unlike counsel for the natural parents, counsel for the de facto parents may be able to advocate adequately the child's interests in the proceedings, despite the presence of their own interest in adopting, ${ }^{144}$ which courts may view as "selfish."145 The law recognizes de facto parents as the best protectors of the child when parental custody is not possible. ${ }^{146}$ As the persons who have been charged with the child's care prior to the proceeding, and to whoin the child is psychologically attached, ${ }^{147}$ they are generally able to advocate the child's best interests and will also often be able to advocate the child's expressed preference. ${ }^{148}$

138. In re Richard E., 21 Cal. 3d 349, 361, 579 P.2d 495, 503, 146 Cal. Rptr. 604, 612 (1978) (Bird, C.J., dissenting).

139. There might be cases where such testimony would be unnecessary, for example, where the parents do not contest the petition.

140. See, e.g., In re Christina L., 118 Cal. App. 3d 737, 748, 173 Cal. Rptr. 722, 728 (2d Dist. 1981); In re Dunlap, 62 Cal. App. 3d at 436, 133 Cal. Rptr. at 314.

141. Mnookin, supra note 55, at 254.

142. Lewis interview, supra note 123.

143. Cal. Governor's Comm'n on the Family, Report 41-42 (1966).

144. Genden, supra note 9, at 569. Professor Bodenheimer suggests several reasons unrelated to the child's interests which may motivate adoptive parents. Bodenheimer, supra note 53, at 16 .

145. See In re Jacqueline H., 94 Cal. App. 3d 808, 814, 156 Cal. Rptr. 765, 768 (2d Dist. 1979).

146. See supra note 32 and accompanying text.

147. See supra notes 43,47 and accompanying text.

148. Brandt interview, supra note 3. See, e.g., In re Heidi T., 87 Cal. App. 3d 864, 877, 151 Cal. Rptr. 263, 269 (1st Dist. 1978). 
There may, however, be cases in which it appears unlikely that counsel for the de facto parents will attempt to advocate adequately a significant interest of the child. Such a case would occur if the child does not want the relation with his or her natural parents to be severed, even if he or she wishes to remain in the care of the de facto parents. ${ }^{149}$ Where the de facto parents nevertheless seek to free the child for adoption, the child's interests in a continued relationship with his or her natural parents should be protected by separate counsel. It is also possible that de facto parents, even if they are deeply attached to the child, will not be considered appropriate custodians by the state. De facto parents may be opposed by the state ${ }^{150}$ either because they are unwillmg to provide the child with the security of formal adoption ${ }^{151}$ or because they are not viewed as proper adoptive parents. ${ }^{152}$ In such cases, the court cannot be assured that counsel for the de facto parents can be rehied on to advocate the child's best interests, and separate counsel should be appointed.

Even where the child's best and professed interests are shared by the de facto parents, separate counsel should be appointed if it appears that de facto parents' counsel is not properly prepared to advocate significant interests of the child. ${ }^{153}$ However, since the de facto parents are inuch more highly motivated than the state in these cases, counsel for the de facto parents can be expected to be encouraged to put more effort into preparing for the proceedings. ${ }^{154}$ On the other hand, de facto parents' counsel is unlikely to have had as much experience with section 232 proceedings as state's counsel and may thus be more likely to advocate an interest of the child inadequately because of a failure to follow important procedures. ${ }^{155}$ Therefore, unless it appears that de facto parents' counsel is familiar with the procedures as well as being

149. See supra notes $45-46$ and accompanying text.

150. The state can recommend against the result they seek in its report. See supra notes 22, 41 and accompanying text.

151. See supra note 119.

152. See supra note 120.

153. Although de facto parents' counsel will have the benefit of the state's report under $\$ 233$, additional facts are likely to be needed. For example, in order to terminate the parents' rights, the court must be convinced that their custody would be detrimental to the child. In cases where the child has long been absent froin the parents-who may since have been rehabilitated-detriment may be provable only by showing that removal from the de facto parents would have a harmful impact on the child. MacGowan, supra note 26, at 6-9; Snyder imterview, supra note 4. In such a case it must be shown that counsel for the de facto parents has investigated sufficiently the facts relevant to the child's emotional needs and is prepared to advocate those needs.

154. In the offices of some county counsel, $\$ 232$ cases may be treated as low priority or low prestige matters. Lewis interview, supra note 123; Snyder interview, supra note 4.

155. See, e.g., In re Dunlap, 62 Cal. App. 3d 428, 436, 133 Cal. Rptr. 310, 314-15 (2d Dist. 1976) (failure to have the probation report entered in evidence) (commented on in In re Richard E., 21 Cal. 3d 349, 353, 579 P.2d 495, 497-98, 146 Cal. Rptr. 604, 606-07 (1978)). 
otherwise well prepared to advocate the child's interests, separate counsel should be appointed.

\section{Making the Determination of the Adequacy of Counsel Already Involved}

The foregoing discussion indicates that the parents' counsel cannot be relied on to advocate the child's interests, that the state's counsel often can, and the de facto parents' counsel sometimes can. At the outset of the proceedimgs, the court must thus determine whether counsel for either the state or the de facto parents can in fact be relied on to advocate the child's interests in the particular case. In making the decision, it is important to avoid creating additional delay, which would be harmful to the child. ${ }^{156}$ Therefore, the determination should probably be made through a conference or other pretrial process, ${ }^{157}$ since postponing the decision until the hearing might require delaying the proceedings to permit counsel for the child to prepare. ${ }^{158}$

\section{a. The Inquiry}

In order to determine whether counsel for the de facto parents or the state can be rehed on to advocate the child's interests, the court must examine the facts and issues involved in the case. The court should first read the petition and the state's report containing informa-

156. See supra note 54 .

157. A number of other methods might be workable. A tramed intake clerk could examine $\$ 232$ petitions and the probation report for signs that counsel should be appointed. Solender, supra note 90 , at 640 . An attorney might be hired to determine whether there is a conflict of interest that would prevent county counsel from representing the child. See 2 CAL. Continuing EDUC. OF THE BAR, supra note $11, \S 15.19$. Alternatively, a guardian ad litem could be appointed to determine the need for counsel. Drabkin interview, supra note 67.

The ability of guardians ad liten to perform this function has been shown in dependency cases. In an innovative program in Los Angeles, trained volunteer guardians ad liten represent children in dependency proceedings and request that the court appoint independent counsel for the child where the child's wishes conflict with the state's position, or if no wishes are expressed, where the position formulated by the guardian based on the child's best interests will not be represented by the state's counsel. Telephone interview with Janet Wiig, Project Manager of the Guardian ad Litein Dependency Court Inprovennent Project, Los Angeles Juvenile Court (Feb. 18, 1982). Under this program, counsel is appointed in $11.5 \%$ of the cases. County Considers Cutting Expense of Child Abuse Cases, The L.A. Daily J., Feb. 11, 1982, at 1, col. 5.

In practice, the issue of counsel for the parent or for the child may be raised long before the hearing. In re Richard E., 21 Cal. 3d 349, 358, 579 P.2d 495, 501, 146 Cal. Rptr. 604, 610 (1978). Furthermore, the question is not necessarily decided by the same judge who eventually hears the case. In re Virgil S., 5 Civ. No. 5738, ship op. at 1 n.1 (5th Dist. Oct. 8, 1981). Another problem in making the determination is that crucial facts inay be missing. For example, § 233 does not specify how long before the hearing the report inust be filed; it may therefore be unavailable in advance of the proceedings. See supra note 22.

158. Section 237.5 provides that the proceedings may be delayed for up to 30 days after appointing counsel. 1981 Cal. Legis. Serv. 2810 (West) (to be codified at CAL. CIv. CODE $§ 237.5$ ). See supro note 8. 
tion about the child's feelings. It may also be advisable for the court to interview the child, if possible. ${ }^{159}$ In addition, counsel for the parties should be asked to summarize their contentions and the evidence and arguments that they will present at the hearing.

Evidence of a possible conflict of interest may sometimes be divulged by the attorneys themselves. This is particularly true of state's counsel, because counsel for the state is viewed as having an affirmative duty to disclose any disability to represent the child. ${ }^{160}$ Disclosure by state's counsel is also arguably required by ethical rules governing analogous proceedings in which the state purports to represent the child. ${ }^{161}$ It may be more difficult for the court to determine that no conflicts exist for the de facto parents' counsel, however, since it has been found to be ethically impermissible for counsel for private parties in a custody dispute to inforin the court that separate counsel is needed. ${ }^{162}$

\section{b. The Finding}

In making the determination of the need for separate counsel, the court is governed by the presumptive rule of Richard $E$. that counsel must be appointed unless an "immediate showing" against counsel is made. ${ }^{163}$ Therefore, unless the court is sure, froin the inforination available that counsel for the state or the de facto parents can be relied on to advocate the child's interests, it should appoint separate counsel. If the court feels that it lacks adequate facts to make a decision or that the decision is a close one, the determination should not be belabored and counsel should be appointed. ${ }^{164}$

In the event separate counsel is not appointed, the court should make a finding in the record indicating its reasons for not appointing counsel. Although failure to make such a showing has been held harmless error, ${ }^{165}$ the wording of the new statute inay cast doubt on this doctrine. ${ }^{166}$ Furthermore, the child's interest in the finality of the

159. See supra note 57.

160. Brandt interview, supra note 3; Drabkin interview, supra note 67.

161. Cal. State Bar, Comm. on Professional Ethics, Formal Op. 1977-45, reprinted in 54 CAL. ST. B.J. 352 (1979).

162. Cal. State Bar, Comm. on Professional Ethics, Formal Op. 1976-37, reprinted in 1 CAL. FAM. L. REP. 1126 (1977).

163. 21 Cal. 3d 349, 355, 579 P.2d 495, 499, 146 Cal. Rptr. 604, 608 (1978).

164. See supra note 54 .

165. See supra note 74 and accompanying text.

166. Although the strengthened language regarding the duty to consider the need for counsel might impliedly overnule Richard E.'s harmless error standard of review, discussed supra in text accompanying notes 74-75, there is no support for this implication in the legislative history. See Assembly Office of Research, Digest of A.B. 344 as amended Aug. 20, 1981 (1981); Legislative Counsel's Digest of A.B. 344 as amended Aug. 20, 1981 (1981); Senate Democratic Caucus, Anal- 
court's decree will be protected by the court's foreclosing this possible argument on appeal.

\section{B. When Requested by the Child}

Separate counsel should also be appointed where the child seeks to participate in the proceedings. The 1981 revisions to section 232 procedure recognize the child's "right" to be present at the hearing ${ }^{167}$ and impliedly recognize a right to participate ineaningfully in the proceedings. ${ }^{168}$ In order to have an effective voice, a child who wishes to take part in the adjudication may need the assistance of counsel whose sole loyalty is to him or her. ${ }^{169}$

There is authority for appointing separate counsel upon request by the child in similar custody proceedings. In dependency cases, which often result in interruption of parental custody, ${ }^{170}$ the child has a right to be present and to be represented by counsel of his or her clioice. ${ }^{171}$ As the California Supreine Court pointed out recently, termination proceedings are unorc drastic than dependency proceedings. Procedural safeguards in termination should therefore be at least equal to those in dependency. ${ }^{172}$

An additional reason for appointing counsel upon a child's requcst is that the acceptability of the result to the child may depend in part on an acceptance of the process through which it was reached. ${ }^{173}$ The state's interest is in providing the child with familial stability, however

ysis of A.B. 344 as amended Aug. 20, 1981 (1981); Senate Republican Caucus, Digest of A.B. 344 as amended Aug. 20, 1981 (1981).

167. See supra note 58 and accompanying text.

168. The new proceedings reflect a concern that the child's position be taken into account. See supra note 97; see also supra notes $56-58$ and accompanying text.

169. For example, where a child wishes to testify in court, he or sle should be prepared for the appearance, which may be a dehicate and lengthy matter, requiring a relation of confidence. Telephone interview with Patricia Bresee, Esq., meinber of panel of counsel appointed to represent minors in San Mateo County (one of the two demonstration counties referred to supra in note 7) (Nov. 19, 1981).

170. See supra note 25.

171. Appointment of separate counsel is discretionary under subdivisions (a), (b), and (c) of CAL. WELF. \& INST. CODE $§ 300$ (West Supp. 1981), but is mandatory when the petition is based on abuse. Id. $\S \S 317,318$. However, the child who is the subject of dependency proceedings has both a right to be present and a right to be represented by counsel of his or her choice. Id. $\$ 349$. Because of these provisions, the child, who often is a dependent, Comment, supra note 1, at 1828, may have had previous experience with counsel and wish to continue to be represented in the termination action. This contimued representation is mandatory in the demonstration counties. CAL. Welf. \& INST. CODE \& 318.5 (West Supp. 1981).

172. This reasoning was used by the California Supreme Court in extending the indigent parents' right to appointed counsel on appeal of termination of parental rights cases. See In re Jacqueline H., 21 Cal. 3d 170, 176, 577 P.2d 683, 687, 145 Cal. Rptr. 548, 552 (1978).

173. See Note, Lawyering for the Child: Principles of Representation in Custody and Visitation Disputes Arising from Divorce, 87 YALE L.J. 1126, 1171 (1978). 
the termination petition is decided. ${ }^{174}$ It is therefore important that the child accept the authority of his or her custodian in the aftermath, thus enabling a parent-child relation to grow. ${ }^{175}$ Giving the child the opportunity to participate in the proceedings through counsel assures that the child will perceive the process as one in which his or her rights were respected and may thus increase the child's acceptance of the result. This rationale, coupled with the practice in dependency cases and the legislative policy evidenced by revisions to section 232 procedures, indicates that courts should appoimt separate counsel for the child if the child requests it.

\section{IV \\ GUIDELINES FOR THE ROLE OF COUNSEL}

In order for section 237.5 to assure the child's interests will be effectively advocated, the role of counsel must be clarified. ${ }^{176}$ Little has been written addressing the role of counsel in termination of parental rights cases, although guidance exists in related areas. ${ }^{177}$ While writers who favor separate counsel concede that, until greater funding and training are devoted to this area appointed counsel inay not greatly further the child's interests, ${ }^{178}$ a necessary first step in improving the ability of counsel to represent the child is to provide guidelines for their performance.

174. See supra notes 34-37.

175. Older children may thwart attempts to provide them with stable placement, if they object to the termination of parental rights. Wald, supra note 4, at 697.

176. See supra notes 84,90 and accompanying text. Section 237.5 itself sets forth no duties of representation but simply requires the court to appoint coumsel if the child's interests require "sucl protection." See supra note 8. "Protection" implies at least ascertaining the child's interests in the case and advocating a result in conformity with these imterests. For sources addressing representation of children in a spectrum of custody actions including termination of parental rights, see IJA-ABA Juvenile Justice Standards, PRivate Parties, supra note 9; Genden, supra note 9, at 565. See also Lucas, Speaking for the Child: A Role Analysis and Some Cautions, in The Rights of Children, EMERgent Concepts in LAW ANd Society 219 (A. Wilkerson ed. 1973); Solender, supra note 90, at 619.

177. For sources on representing minors in divorce custody procecdings, see Holz, supra note 90; Note, supra note 173. On representing minors in proceedings based on abuse or neglect, see Cal. Welf. \& Inst. Code $\$ 318$ (West Supp. 1981); 2 Cal. Continuing Educ. of the Bar, supra note 11; Fraser, Independent Representation for the Abused and Neglected Child: The Guardian Ad Litem, 13 CAL. W.L. REv. 16 (1976). Under California law, abuse and neglect proceedings are generally brought under CAL. WELF. \& INST. CODE § 300 (West Supp. 1981). See supra note 25. As these proceedings are inore frequent than termination actions, the Bresee interview, supra note 169 , and the Lewis interview, supra note 123 , focused in part on dependency representation. Dependency cases also involve issues similar to those in termination cases. See supra text accompanying note 172. Therefore, sources on dependency representation, including the Bresee and Lewis interviews, provide the basis for inucli of what is suggested liere.

178. See Bodenheimer, supra note 53, at 101-02; Genden, supra note 9, at 589-92. 


\section{A. Investigating the Child's Interests and Possible Alternative Outcomes}

Counsel representing the child should investigate the facts relevant to the child's interests as fully as the case requires. ${ }^{179}$ The investigation should include all interests of the child upon which further action can be taken. ${ }^{180}$ There are two obvious starting points: previously compiled facts about the child and the child. Counsel should, therefore, carefully interview the child ${ }^{181}$ and thoroughly read the probation report and files already prepared by state agencies. ${ }^{182}$ Knowledgeable persons already involved im the case should also be consulted, particularly inental health professionals, social workers, and foster parents. ${ }^{183}$ If these sources do not provide sufficient facts about the child, more information should be sought. ${ }^{184}$ Counsel inay look to other persons familiar with the child, such as siblings, teachers, or doctors. ${ }^{185}$ If necessary, counsel inay also request that the court order a psychological evaluation of the child. ${ }^{186}$

The investigation of possible alternative outcomes may be called for by the child's needs or wishes. ${ }^{187}$ If the child desires something less

179. See Cal. Welf. \& Inst. Code § 318(d) (West Supp. 1981); 2 Cal. Continuing Educ. OF THE BAR, supra note 11, §§ 16.16, 16.20; Isaacs, The Role of the Lawyer in Representing Minors in the New Family Court, 12 BufFalo L. Rev. 501, 506 (1963). Counsel should assure that the court is provided with at least the facts courts generally consider relevant. See supra text accompanying notes 130-33. For checklists of information thought indispensable in other custody proceedings, see 2 CAL. Continuing Educ. OF THE BAR, supra note 11, § 16.16; Holz, supra note 90, at 748 .

180. See 2 Cal. Continuing Educ. of the Bar, supra note $11, \S 15.32$. Cf. CAl. Welf. \& INST. CODE $\S 318$ (West Supp. 1981) (similar investigation required in child abuse proceedings).

181. Note, supra note 173, at 1160; Bresee interview, supra note 169; Lewis interview, supra note 123.

182. Where the child has been in foster care, several county agencies may have files pertaining to him or her. In one county studied, these imcluded the Department of Social Services, the Probation Department, and Mental Health Services. Sorrells, supra note 5, at 5. In addition, where the child is a dependent of the court under CAL. WeLF. \& INST. Code $\S 300$ (West Supp. 1981 ), there will be a file on dependency proceedings. There are annual juvenile court reviews of this status, and placeinent may be changed by court order. Id. at $\S 366$. All of these files may be consolidated by the petitioning agency. CAL. CIv. CODE $\$ 233.6$ (West Supp. 1981). The file is available to counsel for the child and to the courts. Bresee interview, supra note 169; Lewis interview, supra note 123. The probation report, prepared under $\$ 233$, is also available to the minor and his or her counsel. CAL. CIV. CODE $\$ 233.5$ (West Supp. 1981).

183. IJA-ABA Juvenile JUSTiCe Standards, Private PARTies, supra note $9, \S 4.3$; Appointment of Guardians Ad Litem, 5 Colo. LAW. 192, 193 (1976); Genden, supra note 9, at 589; Note, supra note 173, at 1181; Bresee interview, supra note 169.

184. See supra notes 130-34 and accompanying text. Moreover, counsel should not passively accept the conclusions of the county agency or probation report, but should verify that they are well-founded. Isaacs, supra note 179, at 507. Natural parents inay not wish to cominunicate with the child's counsel, but their imput should be welcomed when they do. Id.

185. Holz, supra note 90 , at 745 ; Note, supra note 173 , at 1182 .

186. 2 Cal. Continuing EdUC. of THE BAR, supra note $11, \S 15.31$.

187. See supra notes $97-98$. 
than total severance of family ties, the feasibility of continued contact with the natural parents, or of permanent, nonadoptive placement could be explored. ${ }^{188}$ Investigating the alternatives also may require the attorney to explore commuinty resources where it may be necessary to refer a child for treatment. ${ }^{189}$

\section{B. Formulating a Position in Conjunction with the Child}

Counsel inust reach the position to be advocated in conjunction with the child and must not be influenced by the desires of third parties. ${ }^{190}$ The position can therefore only be formulated after a full consultation with the child in which the alternatives and their consequences are presented. ${ }^{191}$ The child's preference should then determine the outcoine to be pursued. ${ }^{192}$ If the child expresses no preference, then counsel must generally draw upon his or her investigation im determining the position to be taken. ${ }^{193}$

The most difficult aspect of formulating a position arises when the attorney's assessment of the child's interests causes him or her to disagree with the outcome sought by the child. ${ }^{194}$ The ethical question of when an attorney representing a child can seek an outcoine contrary to the child's wishes is generally answered on the basis of the child's age $^{195}$ and ability to reach a reasoned decision. ${ }^{196}$ Given the drastic

188. See supra note 122.

189. IJA-ABA Juvenile Justice Standards, Private Parties, supra note 9, \$ 5.3.

190. Section 237.5 provides that counsel for the child shall not be the same as counsel for the parents. Supra note 8. In addition, the legislative history of $\$ 237.5$ as reenacted shows that appointment of county counsel to represent the ehild was proposed and speeifieally excluded. CAL. Legislature, Assembly Daily Journal, 1981-82 sess., at 936 (Mar. 9, 1981). See also ABA Code of Professional Responsibility EC 5-21 (1978).

191. ABA Code of Professional Responsibility EC 7-8, 7-12 (1978); IJA-ABA Juvenile Justice Standards, Private Parties, supra note 9, \$ 3.1(b)(ii)[b].

192. ABA Code of Professional Responsibility EC 7-12 (1978); IJA-ABA Juvenile JusTICE Standards, Private Parties, supra note 9, \$ 3.1, introduction at 2-8.

193. ABA Code of Professional Responsibility EC 7-12 (1978). The IJA-ABA Juvenile Justice Standards, Private Parties, supra note 9, \$ 3.1, suggests a number of other options. Appoimtment of a guardian ad litein can be sought, the least restrictive alternative can be advocated, or a neutral stance taken. But see infra diseussion in note 200 as to the unacceptability of neutrality.

194. Genden, supra note 9, at 589; Note, supra note 173, at 1169.

195. There is authority for treating children aged 14 and over as capable of reaching a position. 2 CAL. Continuing Educ. of THE BAR, supra note $11, \$ \$ 15.30,15.31$, argues that at this age the ehild's wishes are determinative under California law, and between ages 7 and 14, they should be presumed binding on the attorney, subject to his or her finding bascd on objective evidence that the child cannot form a competent preference. In the demonstration counties, termination will not be granted if a child 14 or over objects. CAL. WELF. \& INST. CoDe \$ $366.5(e)(1)(B)$ (West Supp. 1981). Professor Wald would set the age at which a child can prevent termination at 10. Wald, supra note 4, at 697 . As $\$ 234$ of the Civil Code gives special recognition to the need of the court to know the position of a child over 10, this age may be an appropriate guideline for the ehild's attorney. 1981 Cal. Legis. Serv. 2809 (West) (to be codified at CAL. Civ. Code $\S 234$ ). 
nature of termination, counsel should not feel free to substitute his or her own judgment for that of the child. ${ }^{197}$ Rather, counsel should attempt to formulate a position that accommodates the child's desires, taking account of his or her need for a secure and stable home. ${ }^{198}$ Knowledge of possible placement or other options should enable counsel to propose a creative solution ${ }^{199}$ that the child finds acceptable.

\section{Advocating the Child's Interests}

Section 237.5 anticipates that counsel will act as the child's advocate, rather than as a neutral advisor to the court. ${ }^{200}$ Therefore once the position has been formulated, counsel should prepare to assert it actively. The advocaey function may begm before the hearing, however. Where complex issues are likely to be presented, substantial research and preparation of legal argument may be called for. ${ }^{201}$ In addition, routme trial preparation of evidence and witnesses may be required. Pretrial negotiation and motions may also be indicated. Where the child seeks reumification, and it appears feasible, counsel could seek a contmuance. ${ }^{202}$ Similarly, a stipulation or an informal agreement regarding visitation could be reached prior to the hearing. ${ }^{203}$

Most importantly, counsel inust advocate the child's interests at the hearing. The court should be explicitly apprised of the child's ex-

196. IJA-ABA Juvenile Justice Standards, Private Parties, supra note 9, \& 3.1(b)(ii)[b]. See also ABA Code of Professional Responsibility EC 7-12 (1978).

197. See Note, supra note 173, at 1186.

198. Lewis interview, supra note 123.

199. See Deinbitz, supra note 90 , at 1314 ; supra notes $188-89$ and accompanying text.

200. The use of the word "counsel" in the statute probably implies an advocacy role. Ardvagh, supra note 117 , at 606 . Furthermore, if less than ordinary legal representation were intended, $\S 237.5$ would be superfluous because there is already authority for appointment of a "suitable party" to represent the child in $\$ 232$ proceedings. CAL. CIV. CODE $\$ 237$ (West Supp. 1981). At one point, the proposed revision of $\$ 237.5$ incorporated and repealed $\S 237$, enabling the court to consider whether the child's interests required a guardian ad liten, counsel, or both. 1981 Cal. Legislature, Assembly Daily Journal, 1981-82 sess., at 363 (Jan. 27, 1981). The language concerning guardians ad litem was excluded by Senate Amendment to A.B. 344 (as amended June 8, 1981). Therefore, § 237 was not repealed. 1981 Cal. Legis. Serv. 2808 (West). Neutral or "amicus curiae" representation is also rejected by the ABA, see IJA-ABA JUVENILE Justice Standards, Private Parties, supra note 9, at Introduction, but is approved under some circumstances, see id. § 3.1(b)(ii)(c)[3]. Neutrality is disapproved of in these circumstances, however, on the ground that an effective case cannot be presented without a known objective. 2 CAL. CONTINUING EDUC. OF THE BAR, supra note $11, \S 25.12$.

201. Holz, supra note 90, at 745; Bresee interview, supra note 169.

202. Brandt interview, supra note 3 . This would also spare the child the enotional buildup of preparing for the proceedings and having the petition demied or continued for failure to provide services or to atteinpt a less drastic alternative. See supra notes 18-19 and accoinpanying text.

203. See supra notes $45 \& 118$ and accompanying text. Such an agreement could also be entered in the court's judgment. Snyder interview, supra note 4. 
pressed interest, ${ }^{204}$ the relevant facts, and the position that has been formulated. Counsel for the child is free to examine and cross-examine witnesses and to introduce independent testimony, as necessary, and must generally be prepared to act as a trial advocate. ${ }^{205}$ In addition, however, counsel should be mindful that although this role shares many characteristics of representation of an adult client, the need for speedy resolution im section 232 proceedings is far more important than it is in most types of cases. ${ }^{206}$ Therefore, counsel should avoid duplicative questioning and generally strive to streamline the proceedings.

Counsel should also verify that all the procedural requirements are met. ${ }^{207}$ As the child has an interest in a secure judginent, this interest is safeguarded by attempting to inake an appeal-proof record, even at the expense of a strategic benefit that might result from another party's failure to object to deficient procedures. ${ }^{208}$ Counsel should therefore carefully examine all records and papers involved in the case and have a thorough knowledge of the procedural requirements of section 232 actions.

\section{Counseling the Child}

To the best of his or ler ability, the attorney must aid the child in coping with the proceedings-before, after, and during the hearing. ${ }^{209}$

204. See 2 Cal. Continuing Educ. of the BaR, supra note 11, § 15.31; Bresee interview, supra note 169; Lewis interview, supra note 123.

205. See Cal. Welf. \& INST. CODE \& 318(d) (West Supp. 1981). For examples of the kind of strategic actions counsel may be called upon to consider at trial, see In re Stanley F., 86 Cal. App. 3d 568, 574, 152 Cal. Rptr. 5, 8 (2d Dist. 1976) (child's counsel seeks to exclude other parties from in-chambers interview with the child) and In re Lisa R., 13 Cal. 3d 636, 639 n.1, 532 P.2d 123, 125 n.1, 119 Cal. Rptr. $475,477 \mathrm{n.1}$ (1975) (child's counsel objects to assertion of paternity by putative father).

206. See supra notes $44,48,54$ and accompanying text.

207. Hatherly, The Role of the Child's Wishes in California Custody Proceedings, 6 U.C.D. L. Rev. 332, 353 (1973). See also In re Gault, 387 U.S. 1, 36 (1967). For examples of such requirements, see supra notes 20-22, 54.

208. Brandt interview, supra note 3. One family court judge suggests that if the court fails to make required findings, counsel "tactfully remind him of his duty." Holz, supra note 90, at 745.

Procedural defects in $\S 232$ adjudication may take a number of forms. See In re Richard E. 21 Cal. 3d 349, 356, 579 P.2d 495, 500, 146 Cal. Rptr. 604, 609 (1978) (failure to comply with hiteral requirements of $\S 4600$ of the Civil Code held not error); In re Jacqueline H., 21 Cal. 3d $170,178,577$ P.2d 683, 688, $145 \mathrm{Cal}$. Rptr. 548, 553 (failure to apprise parent of her right to appointed counsel on appeal); In re Geoffrey G., 98 Cal. App. 3d 412, 426-27, 159 Cal. Rptr. 460, 468-69 (5th Dist. 1979) (Hopper, J., dissenting) (failure to record the hearing on the petition).

209. IJA-ABA Juvenile Justice Standards, Private Parties, supra note $9, \S 5.3$, and commentary at 116-19 (attorneys who engage in juvenile court representation should be prepared to counsel the client in nonlegal matters). This may include referral for professional mental health counseling or other services. See supra note 189 and accompanying text. Even where appointment of counsel is not necessary, there is often a need for nonlegal advocacy of the sort which could also be provided by trained volunteers, acting as guardians ad litem. Snyder interview, supra note 4; Wiig interview, supra note 157. 
Initially, counsel should describe the roles of the attorneys, the child, and the court in the decisionmaking process. ${ }^{210}$ It nay in soine cases be important to attempt to relieve the child of an undue sense of responsibility for the outcome. ${ }^{211}$ In addition, acting as counselor entails fully explaining each stage of the proceedings to the child and preparmg the child for whatever level of participation is chosen. ${ }^{212}$ Involving the child in the process may enhance his or her self-esteem and counter the overwlielming feeling of having a major decision about his or her life made by an all-powerful stranger. ${ }^{213}$ The child slould be left free to withdraw from the proceedings, lowever, as participation may be painful. ${ }^{214}$ Finally, the counseling role entails attempting to minimize acrimony arising among the parties ${ }^{215}$ and to protect the child from its effects. ${ }^{216}$

\section{CONCLUSION}

Actions to free children for adoption by terminatimg parental rights implicate important interests of the child, as well as interests of the parents, the state, and possibly the de facto parents. Through California Civil Code section 237.5, the legislature and the courts have endeavored to protect the child's interests in tle proceedings by assuring that they receive the representation they require. Although section 237.5 does not mandate that counsel be appointed in every case, a judicially created rule requires that counsel be appointed at the outset of every case absent an affirmative showing that appointment of separate counsel is not needed to protect the child's interests. Courts liave had difficulty, however, deriving a complete set of considerations for determining when counsel is needed and defining the role counsel for the child should play if appointed.

Properly construed, section 237.5 requires that the child's interests, including his or her expressed desires, be advocated in every case and

210. Note, supra note 173, at 1161; Bresee interview, supra note 169.

211. Ardvagh, supra note 117, at 583; Wald, supra note 4, at 697.

212. ABA CODE of Professional Responsibility EC 7-7, 7-8 (1978); see supra notes 16769 and accompanying text. The attorney should gear explanations and advice to the client's age and experience. 2 CAL. Continuing Educ. OF THE BAR, supra note $11, \S 15.29$. Counsel who represent minors develop their own strategies for building trust and establishing a rapport with the child. Bresee interview, supra note 169. See Note, supra note 173, at 1161, 1162.

213. Note, supra note 173, at 1164 \& n.184, 1171; Bresee interview, supra note 169.

214. Note, supra note 173, at 1165-66; see supra note 91.

215. Cf. Note, supra note 173 , at $1172-76$ (counsel for the child in divorce custody cases is ideally suited to reduce the impact of the adversarial proceedings on the child).

216. Particularly in private $\S 232$ petitions, there may be considerable liostility between the parties. See In re Geoffrey G., 98 Cal. App. 3d 412, 426, 159 Cal. Rptr. 460, 468 (5th Dist. 1979) (Hopper, J., dissenting); In re Dunlap, 62 Cal. App. 3d 428, 433-34, 133 Cal. Rptr. 310, 312-13 (2d Dist. 1976). 
that separate counsel be appointed if no counsel already involved can be relied on to perform this advocacy adequately. The court's most difficult task is therefore to determine whether counsel for one of the parties will be able to advocate the child's interests. As shown, while counsel for the natural parents cannot be relied on to protect the child's imterests, counsel for the state and the de facto parents can, so long as it does not appear that a significant interest of the child either will not in fact be advocated or, due to lack of preparation, will not be advocated adequately. If, at the outset of the case, the court is not convinced that counsel for the state or the de facto parents will adequately advocate the child's interests, the presumptive rule requires that separate counsel be appointed. In addition, in view of the child's interest in participating in the proceedings and the child's right to appointed counsel in similar custody actions, separate counsel should also be appointed whenever the child so requests.

If appointed, counsel for the child must fully investigate the child's interests and the possible alternative outcoines. After consultimg with the child, counsel must then formulate a position to be taken in the proceedings. In addition, counsel nuust act as an advocate during the proceedings, being vigilant as to their speed and regularity, and should inforn the child of the significance of each step. Further development of these guidelines for the performance of appointed counsel is important, because if the interests of the child are to be adequately protected in termination proceedings, knowing what to do when appoimted is as essential as knowing when to appoint.

Jennifer Bellah*

- A.B. 1978, Bryn Mawr College; third-year student, Boalt Hall School of Law, University of California, Berkeley. 


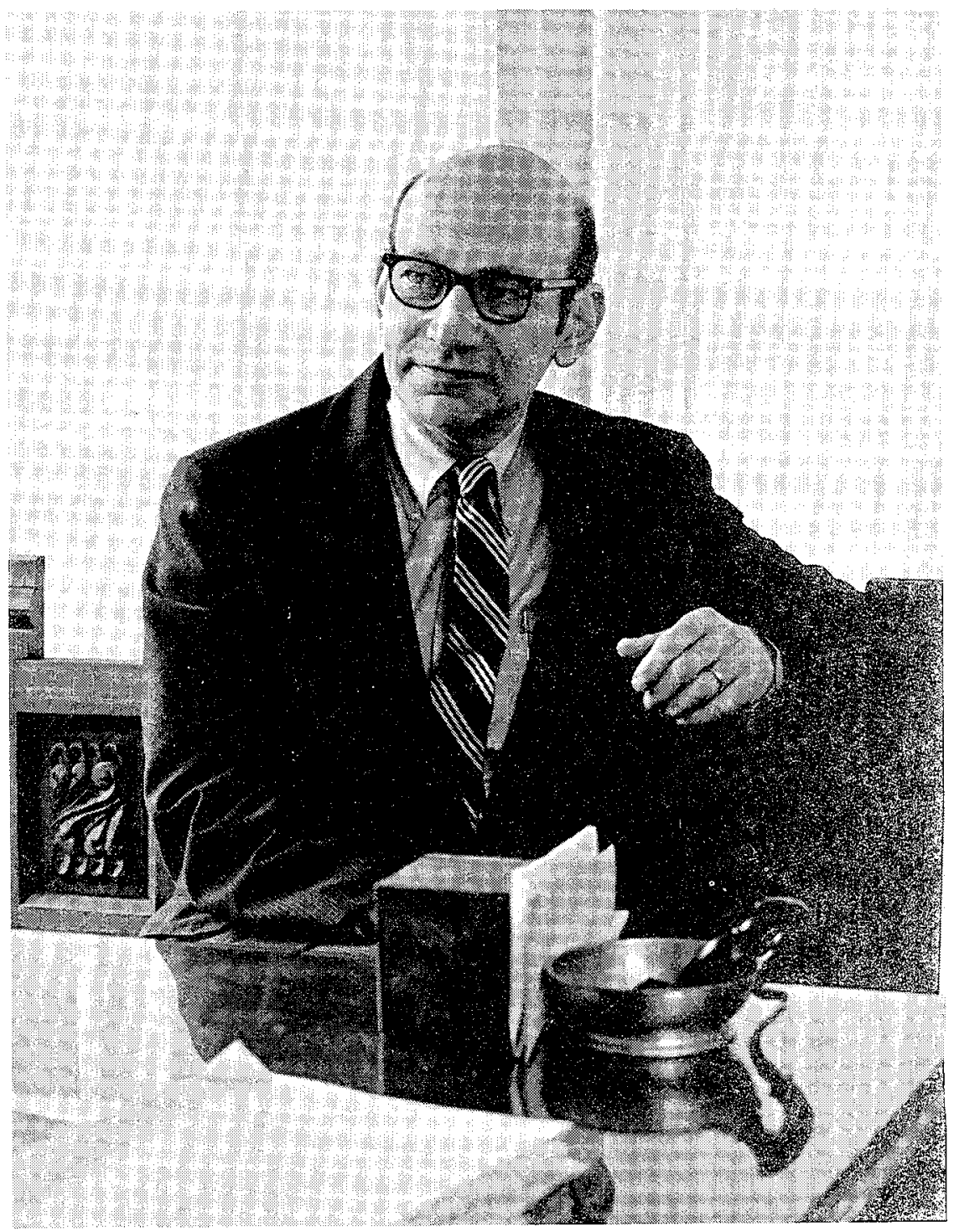

SANFORD $H$. KADISH 
